\title{
Inhaled glycopyrrolate for the treatment of chronic obstructive pulmonary disease
}

This article was published in the following Dove Press journal:

International Journal of COPD

\author{
Donald P Tashkin' \\ Nicholas J Gross ${ }^{2}$ \\ 'Department of Medicine, David \\ Geffen School of Medicine at UCLA, \\ Los Angeles, CA, USA; '2Department \\ of Medicine, University Medical \\ Research LLC, Saint Francis Hospital \\ and Medical Center, Hartford, \\ CT, USA
}

\begin{abstract}
Long-acting muscarinic antagonists (LAMAs), along with long-acting $\beta_{2}$-agonists (LABAs), are the mainstay for treatment of patients with COPD. Glycopyrrolate, or glycopyrronium bromide, like other LAMAs, inhibits parasympathetic nerve impulses by selectively blocking the binding of acetylcholine to muscarinic receptors. Glycopyrrolate is unusual in that it preferentially binds to $\mathrm{M}_{3}$ over $\mathrm{M}_{2}$ muscarinic receptors, thereby specifically targeting the primary muscarinic receptor responsible for bronchoconstriction occurring in COPD. Inhaled glycopyrrolate is slowly absorbed from the lungs and rapidly eliminated from the bloodstream, most likely by renal excretion in its unmetabolized form, limiting the potential for systemic adverse events. Inhaled glycopyrrolate is a fast-acting, efficacious treatment option for patients with moderate-severe COPD. It improves lung function, reduces the risk of exacerbations, and alleviates the symptoms of breathlessness, which in turn may explain the improvement seen in patients' quality of life. Inhaled formulations containing glycopyrrolate are well tolerated, and despite being an anticholinergic, few cardiovascular-related events have been reported. Inhaled glycopyrrolate is thus of value as both monotherapy and in combination with other classes of medication for maintenance treatment of COPD. This review covers the mechanism of action of inhaled glycopyrrolate, including its pharmacokinetic, pharmacodynamic, and safety profiles, and effects on mucus secretion. It also discusses the use of inhaled glycopyrrolate in the treatment of COPD, as monotherapy and in fixed-dose combinations with LABAs and inhaled corticosteroid-LABAs, including a triple therapy recently approved in Europe.
\end{abstract}

Keywords: glycopyrronium bromide, long-acting muscarinicantagonist, anticholinergic, bronchodilator

\section{Plain language summary}

Patients with COPD have narrowed airways and cannot fully empty their lungs, which together can make breathing uncomfortable. Doctors often prescribe an inhaler containing drugs that widen the airways or reduce inflammation in the lungs, making it easier for patients with COPD to breathe. Patients who do not show enough benefit from treatment with one drug alone may be given two or more drugs, which can be combined into one inhaler. One drug used to widen the airways in patients with COPD is glycopyrrolate (also referred to as glycopyrronium bromide). Glycopyrrolate can be used to treat COPD on its own, as well as in combination with other drugs. In this article, we discuss the evidence for how glycopyrrolate works in the body, how glycopyrrolate enters and leaves the body, and the effectiveness and side effects of glycopyrrolate when used to treat patients with COPD in clinical trials alone and combined in one inhaler with another airway-widening drug with or without a drug used to reduce inflammation in the lungs.

\section{Introduction}

Long-acting muscarinic antagonists (LAMAs) or long-acting $\beta_{2}$-agonists (LABAs), alone or in combination, are the mainstay for the maintenance treatment of patients 
with COPD. ${ }^{1,2}$ In the $1980 \mathrm{~s}$, inhaled glycopyrrolate, also known as glycopyrronium bromide, was found to be a longacting bronchodilator ${ }^{3,4}$ and improved pulmonary function after exercise in patients with asthma, ${ }^{5}$ although inhaled glycopyrrolate is not currently licensed for use in asthma. ${ }^{6}$ Inhaled glycopyrrolate, a rapid-onset LAMA, is now US Food and Drug Administration (FDA)- and European Medicines Agency (EMA)-approved for maintenance treatment of patients with COPD. ${ }^{1,6,7}$ This review covers the mechanism of action of inhaled glycopyrrolate, its pharmacokinetic (PK) and pharmacodynamic (PD) profiles, safety profile, effects on mucus secretion, and use in the treatment of COPD as monotherapy and in fixed-dose combinations (FDCs) with LABAs and inhaled corticosteroid (ICS)-LABAs.

\section{Pharmacokinetics and pharmacodynamics of inhaled glycopyrrolate}

Preganglionic parasympathetic nerves innervate the airways via the vagus nerve (Figure 1). ${ }^{8}$ At parasympathetic ganglia, preganglionic nerves synapse with postganglionic nerves. ${ }^{8}$ Acetylcholine (ACh) is a neurotransmitter that is released during parasympathetic nerve impulses and acts by binding to and activating muscarinic receptors and nicotinic receptors. ${ }^{8,9}$ There are five muscarinic receptor subtypes, referred to as $\mathrm{M}_{1}-\mathrm{M}_{5}{ }^{9}{ }^{9}$

$M_{1}$ receptors are highly expressed in the peripheral airways, whereas $M_{2}$ and $M_{3}$ receptors predominate in the larger airways. ${ }^{8} \mathrm{M}_{3}$ receptors are the muscarinic receptors primarily responsible for ACh-induced bronchoconstriction, ${ }^{8}$ as they activate phospholipase $\mathrm{C}$, which produces inositol 1,4,5-triphosphate and diacylglycerol, leading to intracellular calcium release. ${ }^{9}$ Anticholinergics block parasympathetic nerve impulses by selectively preventing ACh from binding to muscarinic receptors. ${ }^{8,10}$ These drugs inhibit bronchoconstriction in peripheral airways by antagonizing the effects on airway smooth muscle cells of ACh released by epithelial cells; this release is stimulated by inflammatory cells. ${ }^{11}$

The anticholinergic effects of inhaled glycopyrrolate are primarily limited to the airways, thereby reducing the

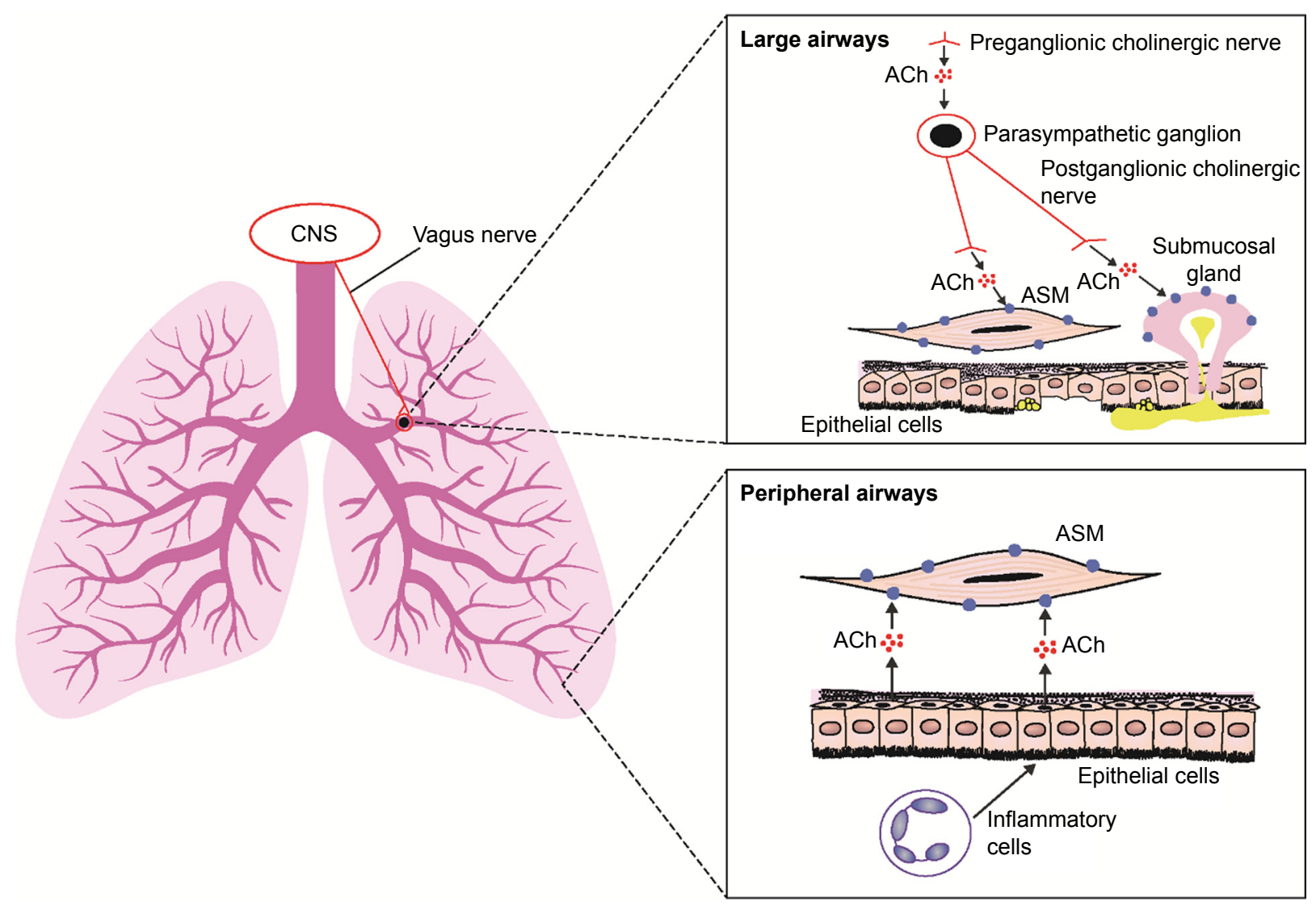

Figure I Role of $\mathrm{ACh}$ and muscarinic receptors in the lung.

Notes: Data from these studies. 11,17 In large airways, ACh released from cholinergic nerves activates $M_{3}$ receptors on ASM, causing bronchoconstriction. In peripheral airways, where cholinergic nerves are absent, inflammatory cells stimulate epithelial cells to release ACh, activating $M_{3}$ receptors on ASM and causing bronchoconstriction. $M_{3}$ muscarinic receptors are shown as solid blue circles. For simplicity, other types of muscarinic receptor are not shown.

Abbreviations: ACh, acetylcholine; ASM, airway smooth muscle; CNS, central nervous system. 
likelihood of systemic adverse events (AEs). ${ }^{12}$ Inhaled glycopyrrolate has a bioavailability of $57 \%$, with $53 \%$ absorbed via the lungs. ${ }^{12}$ Based on its ability to inhibit methacholine-induced calcium release (half-life $\left[t_{1 / 2}\right] 6.1 \pm 2.1$ minutes), inhaled glycopyrrolate has a rapid onset of action. ${ }^{13}$ Inhaled glycopyrrolate is long lasting in the body, with a terminal elimination-phase $t_{1 / 2}$ of 52.5 hours following inhalation (vs $t_{1 / 2}$ of 6.2 hours following intravenous administration). ${ }^{12}$ Population PK modeling has shown that inhaled glycopyrrolate is absorbed slowly, predominantly unchanged, from the lungs. ${ }^{12}$ It has a slow-phase absorption $t_{1 / 2}$ of 3.5 days, accounting for $79 \%$ of drug absorption. ${ }^{12}$ Furthermore, inhaled glycopyrrolate is eliminated rapidly from the bloodstream. ${ }^{12}$ Intravenous glycopyrrolate is excreted, mainly in its unmetabolized form, by the kidney. ${ }^{14,15}$ Metabolism is less important for the elimination of this drug from the body..$^{14,15}$ Renal excretion is also likely to be important for the elimination of glycopyrrolate systematically absorbed from the lung. ${ }^{15}$ However, no inhaled glycopyrrolate dose adjustments are required for patients with mild-moderate renal impairment, and those with severe renal impairment may be given inhaled glycopyrrolate if the benefits are judged to outweigh the risks. ${ }^{6}$

\section{Pharmacokinetic and pharmacodynamic profiles of inhaled glycopyrrolate vs other LAMAs}

Available anticholinergic drugs bind to all muscarinic ACh receptors present in the airways (ie, $\mathrm{M}_{1}-\mathrm{M}_{3}$ ). ${ }^{8}{ }^{16}$ Importantly, $\mathrm{M}_{3}$ receptors are the primary therapeutic target for bronchodilation, with antagonism at $\mathrm{M}_{2}$ autoreceptors tending to attenuate bronchodilator effects. ${ }^{17}$ The PK and PD profiles of glycopyrrolate have been compared with other LAMAs in various preclinical studies, although not all of these studies tested the inhaled delivery of glycopyrrolate (Table 1). 13,16,18,19 Glycopyrrolate is the only anticholinergic to date to show higher relative affinity for $\mathrm{M}_{3}$ than $\mathrm{M}_{2}$ receptors, although its absolute binding affinity for these receptors is lower than that of aclidinium and tiotropium. ${ }^{13,16}$ Glycopyrrolate, aclidinium, tiotropium, and ipratropium (a short-acting muscarinic antagonist) all dissociate more rapidly from $\mathrm{M}_{2}$ than $\mathrm{M}_{3}$ receptors, with all four drugs showing similar ratios of dissociation $t_{1 / 2}{ }^{13,16}$

Table I Preclinical studies comparing the pharmacological profile of glycopyrrolate with other LAMAs and ipratropium

\begin{tabular}{|c|c|c|c|c|c|}
\hline Study & Characteristic & Glycopyrrolate & Aclidinium & Tiotropium & Ipratropium \\
\hline \multirow[t]{4}{*}{ In vitro calcium assay ${ }^{13}$} & $\begin{array}{l}\text { Equilibrium binding constant, } \\
\text { mean } \pm \text { SE: }\end{array}$ & & - & & - \\
\hline & $M_{2}$ & $8.70 \pm 0.04$ & & $10.05 \pm 0.03$ & \\
\hline & & $9.59 \pm 0.05$ & & $10.37 \pm 0.04$ & \\
\hline & $\begin{array}{l}\text { Drug binding } t_{1 / 2} \text { (minutes) at } M_{3} \text { vs } M_{2} \\
\text { receptors (kinetic selectivity ratio) }\end{array}$ & II .4 vs I.07 (I0.7) & - & 46.2 vs $10.8(4.3)$ & - \\
\hline \multirow[t]{3}{*}{$\begin{array}{l}\text { In vitro study of recombinant } \\
\text { human receptors }{ }^{16}\end{array}$} & $\begin{array}{l}\text { Muscarinic receptor-binding affinity } \\
\left(\mathrm{K}_{\mathrm{i}}, \mathrm{nM}\right) \text {, mean } \pm \mathrm{SE} \text { : }\end{array}$ & & & & \\
\hline & $M_{2}$ & $1.77 \pm 0.06$ & $0.14 \pm 0.04$ & $0.13 \pm 0.04$ & $1.12 \pm 0.13$ \\
\hline & $M_{3}$ & $0.52 \pm 0.04$ & $0.14 \pm 0.02$ & $0.19 \pm 0.04$ & $1.24 \pm 0.08$ \\
\hline Ex vivo binding in rat lungs ${ }^{18}$ & $\begin{array}{l}\text { Binding to muscarinic receptors } \\
\text { in lung }\end{array}$ & $\begin{array}{l}\text { Binding lasted } \\
24 \text { hours }\end{array}$ & - & $\begin{array}{l}\text { Binding lasted } \\
24 \text { hours }\end{array}$ & $\begin{array}{l}\text { Binding observed } \\
\text { at } 2 \text { hours, but } \\
\text { not at } 12 \text { hours }\end{array}$ \\
\hline $\begin{array}{l}\text { In vitro study of recombinant } \\
\text { human receptors }{ }^{16}\end{array}$ & $\begin{array}{l}M_{3} \text { vs } M_{2} \text { receptors, dissociation } t_{1 / 2} \\
\text { in hours (kinetic selectivity ratio) }\end{array}$ & 8.1 vs I.I (7.3) & 29.2 vs $4.7(6.2)$ & 62.2 vs I5.I (4.I) & 0.5 vs $0.1(5.9)$ \\
\hline In vivo study in guinea pigs ${ }^{16}$ & $\begin{array}{l}\text { Onset of action (hours) } \\
\text { postadministration }\end{array}$ & 2 & 2 & 4 & 2 \\
\hline $\begin{array}{l}\text { Ex vivo study in human } \\
\text { airways }{ }^{19}\end{array}$ & $\begin{array}{l}\text { Onset of action of I } \mu \mathrm{M} \text { dose, } \\
\text { minutes } \pm \text { SEM }\end{array}$ & $3.4^{\mathrm{a}} \pm 0.4$ & $6.4 \pm 0.5$ & $8.4 \pm 1.1$ & - \\
\hline $\begin{array}{l}\text { In vitro study in guinea pig } \\
\text { trachea }^{16}\end{array}$ & $\begin{array}{l}\text { Duration of action ( } t_{1 / 2} \text { offset of } \\
\text { electrically stimulated contractions) } \\
\text { at } M_{3} \text { receptors }\end{array}$ & $>8$ hours & $>8$ hours & $>8$ hours & 42 minutes \\
\hline In vivo study in guinea pigs ${ }^{16}$ & $\begin{array}{l}\text { Duration of bronchodilator action, in } \\
\text { hours ( } t_{1 / 2} \text { offset of maximal inhibitory } \\
\text { effect) }\end{array}$ & 13 & 29 & 64 & 8 \\
\hline In vivo rat salivation study ${ }^{16}$ & $\mathrm{ED}_{50}(\mu \mathrm{g} / \mathrm{kg})$ for inhibition of salivation & 0.74 & 38 & 0.88 & - \\
\hline In vitro human plasma study ${ }^{16}$ & Hydrolysis $t_{1 / 2}$ in plasma (hours) & 6 & 0.04 & 1.6 & 33 \\
\hline
\end{tabular}

Notes: a $<0.05$ vs both aclidinium and tiotropium at equal concentrations. "-" indicates data not available.

Abbreviations: $\mathrm{ED}_{50}$, dose required to inhibit salivation in $50 \%$ of rats; $\mathrm{K}_{i}$, antagonist dissociation constant; LAMAs, long-acting muscarinic antagonists; $\mathrm{SE}$, standard error; SEM, standard error of the mean; $t_{1 / 2}$, half-life. 
In addition, glycopyrrolate has a shorter absolute dissociation time at both $\mathrm{M}_{2}$ and $\mathrm{M}_{3}$ receptors than at aclidinium and tiotropium. ${ }^{16}$ An ex vivo study examining muscarinic receptor binding in the rat lung showed receptor binding lasted 24 hours for glycopyrrolate and tiotropium, whereas ipratropium binding was observed at 2 hours, but not at 12 hours. ${ }^{18}$

In an in vivo study on guinea pigs, glycopyrrolate, ipratropium, and aclidinium had a similar onset of action, which was more rapid than tiotropium. ${ }^{16}$ However, in isolated human airways, glycopyrrolate had significantly more rapid onset of action than both aclidinium and tiotropium. ${ }^{19}$ Glycopyrrolate had a similar duration of action at $\mathrm{M}_{3}$ receptors to that of aclidinium and tiotropium in vitro, but had a shorter duration of action than tiotropium and aclidinium in vivo in guinea pig studies. ${ }^{16}$ Sykes et al proposed that drug molecules, once dissociated from their target receptors, may not be able to diffuse away from the receptor environment and thus are likely to rebind to localized receptors. ${ }^{13}$ The authors suggested that this may explain why some LAMAs have a long duration of action, despite rapid dissociation rates. ${ }^{13}$ In an in vitro study, aclidinium was shown to have lower stability than tiotropium, which in turn had lower stability than glycopyrrolate in rat, guinea pig, and human plasma. ${ }^{16}$ This indicates that glycopyrrolate undergoes a slower rate of hydrolysis, which may result in a propensity to cause anticholinergic AEs in patients with COPD. ${ }^{16}$ These findings are in agreement with a previous study that compared the plasma stability of aclidinium with tiotropium and ipratropium, with aclidinium found to be the least stable of the three bronchodilators evaluated. ${ }^{20}$ Furthermore, a lower dose of glycopyrrolate and tiotropium than aclidinium is required to inhibit salivation effectively in rats, possibly because of the slower rate of hydrolysis in the blood. ${ }^{16}$

\section{Inhaled glycopyrrolate: effects on mucus secretion and mucociliary clearance in COPD}

Mucus is secreted by submucosal mucus glands and goblet cells in the bronchi, and excessive mucus secretion is a feature of chronic bronchitis and COPD. ${ }^{21} \mathrm{M}_{1}$ and $\mathrm{M}_{3}$ receptors are expressed at a 1:2 ratio in submucosal glands. ${ }^{22}$ The $M_{3}$ receptor is involved primarily in mediating mucus secretion, whereas water and electrolyte secretion are likely to be regulated by $\mathrm{M}_{3}$ and $\mathrm{M}_{1}$ receptors in combination. ${ }^{22}$ LABAs are known to enhance mucociliary clearance in patients with COPD,${ }^{23}$ probably via an effect on ciliary beat frequency, ${ }^{24}$ and there are numerous theories regarding the alteration of mucus production by LAMAs. ${ }^{25}$ However, the results from clinical trials testing these theories are conflicting. ${ }^{25}$
In an open-label, non-placebo-controlled trial in 22 patients with COPD, tiotropium reduced cough symptoms and nasal clearance times. ${ }^{26}$ The authors concluded that this effect may result from inhibition of mucus hypersecretion and an increase in mucociliary clearance in the airways. ${ }^{26}$ However, this supposition is not supported by other studies: in a randomized, double-blind trial, Hasani et al failed to find an effect of tiotropium on mucociliary clearance in 34 patients with COPD, ${ }^{27}$ whereas Meyer et al reported that tiotropium treatment slowed mucociliary clearance in their randomized, open-label, crossover study in 24 patients. ${ }^{28}$ Furthermore, in a double-blind, crossover study, ipratropium was actually found to decrease cough clearance of secretions in patients with COPD. ${ }^{29}$

Oral glycopyrrolate is known to reduce drooling in children, and glycopyrrolate injections can reduce preoperative salivation, as well as respiratory secretions during endof-life care. ${ }^{30,31}$ However, on review of published literature cited in PubMed, no studies could be found that examined the role of inhaled glycopyrrolate in mucus secretion. There also appear to be limited published data examining the effect of glycopyrrolate on mucociliary clearance, ${ }^{25}$ and hence, there is a need for further study in this area.

\section{The effect of inhaled glycopyrrolate on cognition}

Glycopyrrolate is a water-soluble, highly polar quaternary ammonium compound, which limits its passage across lipid membranes such as the blood-brain barrier; therefore, glycopyrrolate does not exhibit any central nervous system activity. ${ }^{32}$ Inhaled glycopyrrolate is thus unlikely to have a significant effect on cognition in patients with COPD, although there is a lack of evidence to support this.

\section{Clinical evidence for the use of inhaled glycopyrrolate in patients with COPD}

In its inhaled form, glycopyrrolate and other approved LAMAs are used for the management of COPD. ${ }^{1,6,33-37}$ Glycopyrrolate is available as a monotherapy via a drypowder inhaler (DPI) ${ }^{6}$ and was approved by the FDA in 2017 as a nebulized monotherapy (Table 2). ${ }^{38}$ Inhaled glycopyrrolate is also available in an FDC with formoterol, delivered using co-suspension delivery technology in a pressurized metered dose inhaler (pMDI), ${ }^{34}$ and in a DPI FDC with indacaterol. ${ }^{35,36}$ Inhaled glycopyrrolate has been approved in Europe as a triple FDC with formoterol and beclomethasone, delivered via a pMDI. ${ }^{39}$ 
Table 2 Available glycopyrrolate and other LAMA formulations

\begin{tabular}{|c|c|c|c|c|}
\hline Formulation & Brand name & $\begin{array}{l}\text { Delivery } \\
\text { method }\end{array}$ & $\begin{array}{l}\text { Regions } \\
\text { approved }\end{array}$ & Approved dosage \\
\hline \multicolumn{5}{|l|}{ Glycopyrrolate formulations } \\
\hline \multirow[t]{2}{*}{ Monotherapy } & Seebri Neohaler & DPI & US & I5.6 $\mu \mathrm{g}$ BID \\
\hline & Seebri Breezhaler & DPI & Europe & $50 \mu \mathrm{g}$ QD (glycopyrronium moiety in capsule) \\
\hline Monotherapy ${ }^{78}$ & Lonhala Magnair & Nebulized & US & $25 \mu \mathrm{g}$ BID \\
\hline Glycopyrrolate-formoterol ${ }^{34}$ & Bevespi Aerosphere & pMDI & US & $\begin{array}{l}\text { I8/9.6 } \mu \mathrm{g} \text { BID (as glycopyrrolate-formoterol } \\
\text { fumarate) }\end{array}$ \\
\hline \multirow[t]{2}{*}{ Glycopyrrolate-indacaterol ${ }^{35,36}$} & Utibron Neohaler & DPI & US & I5.6/27.5 $\mu \mathrm{g}$ BID \\
\hline & Ultibro Breezhaler & DPI & Europe & $\begin{array}{l}50 / I 10 \mu \mathrm{g} Q \mathrm{QD} \text { (in capsule, as glycopyrronium/ } \\
\text { indacaterol) }\end{array}$ \\
\hline $\begin{array}{l}\text { Glycopyrrolate-beclomethasone- } \\
\text { formoterol }^{37}\end{array}$ & Trimbow & pMDI & Europe & $\begin{array}{l}\text { I2.5/I00/6 } \mu \mathrm{g} \text { BID (metered dose, as } \\
\text { glycopyrronium bromide-beclomethasone } \\
\text { dipropionate-formoterol fumarate dihydrate) }\end{array}$ \\
\hline \multicolumn{5}{|l|}{ Tiotropium formulations } \\
\hline \multirow[t]{2}{*}{ Monotherapy 79,80} & Spiriva HandiHaler & DPI & US & I8 $\mu \mathrm{g}$ QD (as tiotropium bromide) \\
\hline & Spiriva Respimat & SMI & US & $5 \mu \mathrm{g}$ QD (as tiotropium bromide) \\
\hline \multirow[t]{2}{*}{ Tiotropium-olodaterol $\left.\right|^{81,82}$} & Stiolto Respimat & SMI & US & $5 / 5 \mu \mathrm{g}$ QD \\
\hline & Spiolto Respimat & SMI & Europe & $\begin{array}{l}5 / 5 \mu \mathrm{g} \mathrm{QD} \text { (delivered dose, as tiotropium } \\
\text { bromide monohydrate-olodaterol hydrochloride) }\end{array}$ \\
\hline \multicolumn{5}{|l|}{ Umeclidinium formulations } \\
\hline \multirow[t]{2}{*}{ Monotherapy ${ }^{83,84}$} & Incruse Ellipta & DPI & US & $62.5 \mu \mathrm{g}$ QD \\
\hline & Incruse Ellipta & DPI & Europe & $62.5 \mu \mathrm{g}$ QD (predispensed dose, as umeclidinium) \\
\hline \multirow[t]{2}{*}{ Umeclidinium-vilanterol 85,86} & Anoro Ellipta & DPI & US & $62.5 / 25 \mu \mathrm{g}$ QD \\
\hline & Anoro Ellipta & DPI & Europe & $\begin{array}{l}\text { 62.5/25 } \mu \mathrm{g} \text { QD (predispensed dose, as } \\
\text { umeclidinium-vilanterol trifenatate) }\end{array}$ \\
\hline $\begin{array}{l}\text { Umeclidinium-fluticasone } \\
\text { furoate-vilanterol }{ }^{87}\end{array}$ & Trelegy Ellipta & DPI & US & $\begin{array}{l}\text { 62.5//00/25 } \mu \mathrm{g} \text { QD } \\
\text { (as umeclidinium-fluticasone furoate-vilanterol) }\end{array}$ \\
\hline \multicolumn{5}{|l|}{ Aclidinium formulations } \\
\hline \multirow[t]{3}{*}{ Monotherapy ${ }^{88-90}$} & Eklira Genuair & DPI & Europe & $400 \mu \mathrm{g}$ BID (as aclidinium bromide) \\
\hline & Bretaris Genuair & DPI & Europe & $400 \mu \mathrm{g}$ BID (as aclidinium bromide) \\
\hline & Tudorza Pressair & DPI & US & $400 \mu \mathrm{g}$ BID (as aclidinium bromide) \\
\hline Aclidinium-formoterol ${ }^{91}$ & Duaklir Genuair & DPI & Europe & $\begin{array}{l}400 / 12 \mu \mathrm{g} \text { BID (as aclidinium bromide- } \\
\text { formoterol fumarate dihydrate) }\end{array}$ \\
\hline \multicolumn{5}{|l|}{ Revefenacin formulation } \\
\hline Monotherapy 92 & $\mathrm{TBC}^{\mathrm{a}}$ & Nebulized & $\begin{array}{l}\text { Completed } \\
\text { Phase III trials }\end{array}$ & NA \\
\hline
\end{tabular}

Note: ${ }^{a}$ Theravance Biopharma and Mylan submitted a new drug application for revefenacin use in patients with COPD in November 2017 and were waiting for a response at the time of submission of this review article. ${ }^{93}$

Abbreviations: BID, bis in die (twice daily); DPI, dry-powder inhaler; LAMA, long-acting muscarinic antagonist; NA, not applicable; pMDI, pressurized metered dose inhaler; $\mathrm{QD}$, quaque die (once daily); SMI, soft-mist inhaler; TBC, to be confirmed.

\section{Efficacy of inhaled glycopyrrolate monotherapy \\ Onset of action}

In a randomized, double-blind study to determine the most appropriate dose of inhaled glycopyrrolate monotherapy (delivered via a DPI) for patients with moderate-severe COPD, glycopyrrolate $50 \mu \mathrm{g}$ once daily (QD) provided significant bronchodilation over 24 hours. ${ }^{40}$ However, the efficacy of glycopyrrolate $50 \mu \mathrm{g}$ QD was not significantly different from the same total daily dose administered twice daily (BID). ${ }^{40}$ The randomized GLOW trials were conducted to evaluate the use of $50 \mu \mathrm{g}$ QD of inhaled glycopyrrolate for treating patients with moderate-severe COPD..$^{41-46}$ The GLOW1 study showed that glycopyrrolate $50 \mu \mathrm{g}$ QD had a rapid onset of bronchodilation in patients with COPD, with a significant improvement from baseline in lung function vs placebo as early as 5 minutes after treatment $(P<0.001){ }^{41}$ Supporting the preclinical data, inhaled glycopyrrolate has been shown to have faster onset of action than tiotropium in several clinical trials. In the randomized GLOW2 study, glycopyrrolate $50 \mu \mathrm{g}$ QD resulted in significantly more rapid bronchodilation than tiotropium $18 \mu \mathrm{g}$ QD treatment at all time points from 5 minutes to 4 hours after the first dose on day $1(P<0.01) .{ }^{42}$ Similarly, in the randomized 
GLOW5 study, glycopyrrolate $50 \mu \mathrm{g}$ QD resulted in significantly more rapid improvement in lung function than tiotropium $18 \mu \mathrm{g}$ QD treatment at 5 and 15 minutes after first dose. ${ }^{45}$ Additionally, in a post hoc analysis of the randomized SPRING study in patients with moderate-severe COPD, glycopyrrolate $50 \mu \mathrm{g}$ QD resulted in a significantly greater improvement in lung function than tiotropium $18 \mu \mathrm{g}$ QD at 5 minutes, 15 minutes, and 1 hour after the first dose on day 1 ( $P=0.015, P=0.026$, and $P=0.014$, respectively).$^{47}$ In a further study in patients with moderate-severe COPD, single doses of both glycopyrrolate $(50 \mu \mathrm{g})$ and aclidinium $(400 \mu \mathrm{g})$ had more rapid onset of action than tiotropium (18 $\mu \mathrm{g})$, resulting in greater levels of bronchodilation 90 minutes after treatment, although the authors concluded that faster onset of action seen in the clinic may not be relevant for patients who are undergoing long-term treatment for chronic disease. ${ }^{19}$

\section{Lung function and other efficacy end points}

The efficacy of inhaled glycopyrrolate monotherapy (via a DPI) has been investigated in patients with COPD in numerous clinical studies, including the GLOW study series and the GEM studies (Table 3). ${ }^{38,41-52}$ Two network metaanalyses have also been conducted to compare the efficacy of glycopyrrolate with other LAMAs. ${ }^{53,54}$ The first (including 21 trials) compared glycopyrrolate $50 \mu \mathrm{g}$ QD with aclidinium $400 \mu \mathrm{g}$ BID, tiotropium $18 \mu \mathrm{g}$ QD (HandiHaler), and tiotropium $5 \mu \mathrm{g}$ QD (Respimat) in patients with moderate-severe COPD. ${ }^{53}$ After 24 weeks, glycopyrrolate $50 \mu \mathrm{g}$ treatment resulted in a similar improvement in lung function compared with aclidinium $400 \mu \mathrm{g}$, tiotropium $18 \mu \mathrm{g}$, and tiotropium $5 \mu \mathrm{g} .{ }^{53}$ At the same time point, glycopyrrolate $50 \mu \mathrm{g}$ treatment resulted in similar improvements in St George's Respiratory Questionnaire (SGRQ) scores from baseline compared with aclidinium $400 \mu \mathrm{g}$ and tiotropium $18 \mu \mathrm{g}$, and a greater improvement compared with tiotropium $5 \mu \mathrm{g} .{ }^{53}$ Improvements in breathlessness symptoms were similar for all treatments. ${ }^{53}$

The second network meta-analysis (including 24 trials) compared the efficacy of glycopyrrolate $50 \mu \mathrm{g}$ QD, tiotropium $18 \mu \mathrm{g}$ QD, aclidinium $400 \mu \mathrm{g}$ BID, and umeclidinium $62.5 \mu \mathrm{g}$ QD in patients with COPD. ${ }^{54}$ At weeks 12 and 24,

Table 3 Clinical evidence of the efficacy of glycopyrrolate monotherapy in patients with COPD

\begin{tabular}{lll}
\hline Clinical trial & $\begin{array}{l}\text { Treatment } \\
\text { duration }\end{array}$ & Treatments
\end{tabular}

GLOW trials: double-blind, randomized, placebo-controlled studies in patients with moderate-severe COPD

Phase III 26 weeks Glycopyrrolate $50 \mu \mathrm{g}$ QD

GLOWI $\quad(n=552)$, placebo $(n=270)$

Glycopyrrolate significantly increased trough $\mathrm{FEV}$, vs placebo at week 12 (LSM treatment difference $0.108 \mathrm{~L}, P<0.00 \mathrm{I}$ ), increase maintained at week 26 (LSM treatment difference 0.1 I $3 \mathrm{~L}, P<0.00$ I) Significant improvements in dyspnea (TDI focal score 1.84 vs 0.80 points, $P<0.00 \mathrm{I})$ and time to first moderate/severe exacerbation $(P=0.023)$ vs placebo at week 26

\begin{tabular}{|c|c|c|}
\hline Phase III & 52 weeks & Glycopyrrolate $50 \mu \mathrm{g}$ QD \\
\hline \multirow[t]{3}{*}{ GLOW2 $2^{42}$} & & $(n=529)$, placebo $(n=269)$ \\
\hline & & open-label tiotropium $18 \mu \mathrm{g}$ \\
\hline & & QD (n=268) \\
\hline
\end{tabular}

Glycopyrrolate significantly increased trough $\mathrm{FEV}$, vs placebo at week 12 (LSM treatment difference $97 \mathrm{~mL}, P<0.00 \mathrm{I}$ )

Glycopyrrolate significantly increased trough FEV, vs tiotropium at week 26 (LSM treatment difference $50 \mathrm{~mL}, P<0.0$ I), while trough FEV, was similar at weeks 12 and 52 (LSM treatment difference 14 and $19 \mathrm{~mL}$, respectively)

Significant improvements in dyspnea at week 26 (TDI focal score 2.13 vs I.32, $P=0.002)$ and risk of exacerbations at week $52(P=0.00 \mathrm{I})$ vs placebo

\begin{tabular}{|c|c|c|c|}
\hline $\begin{array}{l}\text { Phase III GLOW3 } \\
\text { crossover }^{43}\end{array}$ & 3 weeks & $\begin{array}{l}\text { Glycopyrrolate } 50 \mu \mathrm{g} \\
\text { QD, then placebo }(n=55) \\
\text { placebo, then glycopyrrolate } \\
50 \mu \mathrm{g} \text { QD }(n=53)\end{array}$ & $\begin{array}{l}\text { Glycopyrrolate significantly improved submaximal exercise endurance } \\
\text { time vs placebo on day I }(P<0.001) \text {, and this improvement increased at } \\
\text { day } 2 \text { I }(P<0.00 \text { I) }\end{array}$ \\
\hline $\begin{array}{l}\text { Phase III } \\
\text { GLOW5 } 5^{45}\end{array}$ & 12 weeks & $\begin{array}{l}\text { Glycopyrrolate } 50 \mu g \text { QD } \\
\text { (n=327), tiotropium } 18 \mu g \\
\text { QD }(n=330)\end{array}$ & $\begin{array}{l}\text { Glycopyrrolate was noninferior to tiotropium for trough } \mathrm{FEV} \text {, at } \\
\text { week I } 2 \text { (LSM treatment difference } 0 \mathrm{~L}, \mathrm{P}<0.00 \mathrm{I} \text { ) } \\
\text { Glycopyrrolate had a significantly faster onset of action on day I than } \\
\text { tiotropium (postdose FEV, at } 0 \text { - to } 4 \text {-hour time points, all } P<0.00 \mathrm{I} \text { ) }\end{array}$ \\
\hline GLOW776 & 26 weeks & $\begin{array}{l}\text { Glycopyrrolate } 50 \mu \mathrm{g} \text { QD } \\
(\mathrm{n}=306) \text {, placebo }(\mathrm{n}=154)\end{array}$ & $\begin{array}{l}\text { Glycopyrrolate significantly improved trough FEV, vs placebo at week I } 2 \\
\text { (LSM treatment difference } 14 \mathrm{I} \mathrm{mL}, P<0.00 \mathrm{I} \text { ) } \\
\text { Glycopyrrolate significantly improved SGRQ scores (LSM treatment } \\
\text { difference }-4.92 \text { points, } P<0.00 \mathrm{I} \text { ) and dyspnea severity (LSM treatment } \\
\text { difference I point, } P<0.00 \mathrm{I} \text { ) at week } 26 \text { vs placebo }\end{array}$ \\
\hline
\end{tabular}

(Continued) 
Table 3 (Continued)

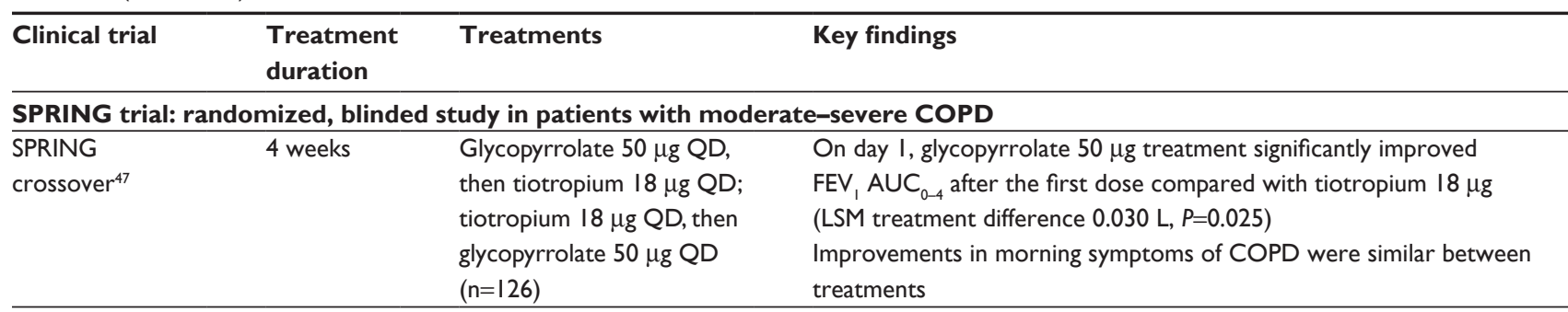

GEM trials: Phase III, double-blind, randomized, placebo-controlled studies in patients with COPD and moderate-severe airflow limitation

\begin{tabular}{lll}
\hline GEMI $^{48}$ & weeks & $\begin{array}{l}\text { Glycopyrrolate } 15.6 \mu g \text { BID } \\
(n=222), \text { placebo }(n=219)\end{array}$
\end{tabular}

Glycopyrrolate significantly improved $\mathrm{FEV}, \mathrm{AUC}_{0-12}$ vs placebo at $(n=222)$, placebo $(n=219)$

week 12 (LSM treatment difference $0.139 \mathrm{~L}, P<0.00 \mathrm{I}$ )

Glycopyrrolate significantly improved TDI (LSM treatment

difference 0.92 points, $P=0.003$ ) and SGRQ scores (LSM treatment difference -2.8 points, $P=0.016$ ) vs placebo at week 12

\begin{tabular}{lll}
\hline GEM2 $^{49}$ & I2 weeks & $\begin{array}{l}\text { Glycopyrrolate } 15.6 \mu \mathrm{g} \text { BID } \\
(n=2 \mid 6), \text { placebo }(n=2 \mid 6)\end{array}$
\end{tabular}

Glycopyrrolate significantly improved $\mathrm{FEV}_{1} \mathrm{AUC}_{0-12}$ vs placebo at day I (LSM treatment difference $0.119 \mathrm{~L}, P<0.00 \mathrm{I}$ ), improvement maintained at week 12 (LSM treatment difference $0.123 \mathrm{~L}, P<0.00 \mathrm{I}$ ) Glycopyrrolate significantly improved SGRQ scores (LSM treatment difference -5.2 points, $P<0.00 \mathrm{I}$ ) vs placebo at week 12

GOLDEN trials: Phase III, randomized studies of nebulized glycopyrrolate in patients with moderate-very severe COPD

Double-blind, $\quad 12$ weeks $\quad$ Glycopyrrolate $25 \mu \mathrm{g}$ BID At week I2, treatment with glycopyrrolate 25 and $50 \mu \mathrm{g}$ BID resulted
placebo-controlled $\quad(n=43 \mathrm{I})$, glycopyrrolate in significant and clinically important improvements in trough $\mathrm{FEV}$, vs GOLDEN 3 and $\quad 50 \mu \mathrm{g}$ BID $(\mathrm{n}=432)$, placebo GOLDEN $4^{38} \quad(n=430)$ placebo (GOLDEN 3 [LSM difference 0.105 and $0.126 \mathrm{~L}$, respectively] and GOLDEN 4 [LSM difference 0.084 and 0.082 L, respectively], all $P \leq 0.000 \mathrm{I}$ )

At week 12, glycopyrrolate 25 and $50 \mu \mathrm{g}$ BID significantly improved trough FVC vs placebo (GOLDEN 3 [LSM difference 0.149 and $0.167 \mathrm{~L}$, respectively; both $P<0.00$ I], GOLDEN 4 [LSM difference 0.130 and 0.113 L, respectively; $P<0.01$ ])

At week I2/end of study, glycopyrrolate 25 and $50 \mu \mathrm{g}$ BID significantly increased SGRQ scores vs placebo (GOLDEN 3 [LSM difference -3.072, $P<0.05$ and -1.848 points, $P=N S$, respectively]; GOLDEN 4 [LSM difference -3.585 and -3.557 points, respectively; $P<0.0 I$ ])

\begin{tabular}{lll}
\hline $\begin{array}{l}\text { Open-label, } \\
\text { active-controlled }\end{array}$ & 48 weeks & $\begin{array}{l}\text { Glycopyrrolate } 50 \mu \mathrm{g} \text { BID } \\
(\mathrm{n}=62 \mathrm{I}), \text { tiotropium I8 } \mu \mathrm{g}\end{array}$ \\
GOLDEN 5 & & QD $(\mathrm{n}=466)$
\end{tabular}
Glycopyrrolate treatment improved trough $F E V_{\text {, from baseline, which }}$ was maintained until week 48 (LSM change from baseline at week 48 $0.069 \mathrm{~L}$ )

Change from baseline in FEV, at 48 weeks did not differ significantly between glycopyrrolate and tiotropium

Randomized, double-blind studies of glycopyrrolate delivered using co-suspension delivery technology in patients with moderate-severe COPD ${ }^{\mathrm{a}}$

Chronic-dosing, $\quad 2$ weeks $\quad$ Glycopyrrolate 18, 9, $\quad$ After I4 days' treatment, glycopyrrolate at doses 18, 9, 4.6, and 2.4 $\mu \mathrm{g}$
Phase II, crossover $\quad 4.6,2.4,1.2,0.6 \mu \mathrm{g}$ BID trial $^{52}(\mathrm{n}=64,64,62,64,57,59$, respectively), open-label tiotropium $18 \mu \mathrm{g}$ QD $(n=62)$, placebo BID $(n=62)$ $\mathrm{BID}$ resulted in significant and clinically relevant improvements in $F E V_{1} A \cup C_{0-12}$ compared with placebo (LSM difference from baseline I26-I58 mL, $P<0.000$ I)

Glycopyrrolate $18 \mu \mathrm{g}$ BID was noninferior to open-label tiotropium $18 \mu \mathrm{g}$ QD for peak change in FEV, on day I (LSM change from baseline 0.23 I vs $0.270 \mathrm{~L}$ ) and morning predose trough FEV, on day I 4 (LSM change from baseline 0.089 vs $0.126 \mathrm{~L}$ ) and was the most appropriate dose for further evaluation

\begin{tabular}{|c|c|c|c|}
\hline $\begin{array}{l}\text { Chronic-dosing, } \\
\text { Phase IIB, } \\
\text { incomplete block, } \\
\text { crossover trial }^{57}\end{array}$ & 7 days & $\begin{array}{l}\text { Glycopyrrolate (as } \\
\text { glycopyrronium) } 28.8,14.4 \text {, } \\
7.2,3.6 \mu g \text { BID ( } n=192) \\
\text { placebo BID ( } n=48) \text {, open- } \\
\text { label ipratropium } 34 \mu g \\
\text { QID }(n=48)^{b}\end{array}$ & $\begin{array}{l}\text { At day } 7 \text {, all glycopyrrolate doses were superior to placebo for } \\
\text { improvement from baseline in } \mathrm{FEV}, \mathrm{AUC}_{0-12} \text { (LSM treatment differences } \\
\text { vs placebo } 0.121-0.191 \mathrm{~L} \text {, all } P<0.000 \mathrm{I} \text { ) } \\
\text { All glycopyrrolate doses were noninferior to ipratropium (data not } \\
\text { shown) } \\
\text { Glycopyrrolate } 28.8 \text { and } 14.4 \mu \mathrm{g} \text { were the most effective doses for } \\
\text { improving all secondary efficacy end points }\end{array}$ \\
\hline
\end{tabular}

Notes: aphase II studies included, as Phase III trial data have not yet been published for this product; beach patient received three treatments of two doses of glycopyrrolate and either placebo or ipratropium.

Abbreviations: AUC, area under curve; BID, bis in die (twice daily); FEV , forced expiratory volume in I second; FVC, forced vital capacity; LSM, least squares mean; NS, not significant; QD, quaque die (once daily); QID, quater in die (four times daily); SGRQ, St George's Respiratory Questionnaire; TDI, Transition Dyspnea Index. 
all LAMA treatments evaluated resulted in clinically relevant $(>100 \mathrm{~mL})$ improvements in trough forced expiratory volume in 1 second $\left(\mathrm{FEV}_{1}\right)$ compared with placebo. ${ }^{54}$ Glycopyrrolate $50 \mu \mathrm{g}$ treatment resulted in the greatest improvement over placebo in lung function at week $24\left(\mathrm{FEV}_{1}\right.$ difference $135.8 \mathrm{~mL}){ }^{54}$ For all LAMAs vs placebo, improvements were seen from baseline in 24-week SGRQ and Transition Dyspnea Index (TDI) scores. ${ }^{54}$ Glycopyrrolate $50 \mu \mathrm{g}$ QD treatment did not reach the minimal clinically important difference (MCID) in SGRQ score of 4 units compared with placebo, but did reach the MCID of $\geq 1$ for TDI focal score. ${ }^{54}$ However, aclidinium $400 \mu \mathrm{g}$ and umeclidinium $62.5 \mu \mathrm{g}$ treatments reached MCID for both SGRQ and TDI focal scores compared with placebo, whereas tiotropium did not reach MCID for either of the two measures. ${ }^{54}$

For patients with moderate-severe COPD, clinical trial data for treatment with inhaled glycopyrrolate as a monotherapy indicate that glycopyrrolate $50 \mu \mathrm{g}$ QD (the EMA-approved dose) improves lung function and health-related quality of life (HRQoL), decreases the severity of breathlessness and the risk of exacerbations, and improves morning symptoms. ${ }^{41,42,45,47,51}$ Furthermore, glycopyrrolate $50 \mu \mathrm{g}$ QD was found to be noninferior to tiotropium in its ability to increase airflow to the lungs. ${ }^{45}$ In a short-term, crossover trial (3-week treatment periods), glycopyrrolate also significantly improved patients' abilities to exercise vs placebo. ${ }^{43}$ In Phase III trials of glycopyrrolate $15.6 \mu \mathrm{g}$ BID (the FDA-approved dose) in patients with moderate-severe COPD, there were also significant improvements in $\mathrm{FEV}_{1}$ scores from baseline, TDI focal scores, and SGRQ scores vs placebo. ${ }^{48,49}$ In two Phase III trials of the nebulized form of glycopyrrolate, $50 \mu \mathrm{g}$ BID treatment resulted in significant and clinically important increases from baseline in lung function and SGRQ scores vs placebo. ${ }^{38}$ Finally, in two studies in patients with moderate-severe COPD, glycopyrrolate was delivered by pMDI using innovative co-suspension delivery technology, which allows aerosol delivery of micronized drug suspended with microsized, phospholipid-based porous particles. ${ }^{52,55-57}$ In these studies, patients treated with glycopyrrolate (doses $\geq 2.4 \mu \mathrm{g}$ BID) showed clinically relevant, significant improvements in lung function from baseline vs placebo. ${ }^{52,57}$ Furthermore, the highest glycopyrrolate dose tested in the first study $(18 \mu \mathrm{g}$ BID) was found to be noninferior to tiotropium $18 \mu \mathrm{g}$ QD for improving lung function. ${ }^{52}$ In the second study, all glycopyrrolate doses (delivered as glycopyrronium 28.8, $14.4,7.2$, and $3.6 \mu \mathrm{g}$ BID) were found to be noninferior to ipratropium $34 \mu \mathrm{g} 4$ times daily. ${ }^{57}$ Based on these studies, $18 \mu \mathrm{g}$ (equivalent to $14.4 \mu \mathrm{g}$ glycopyrronium) was selected as the optimal glycopyrrolate dose for the glycopyrrolateformoterol combination studies. ${ }^{52,57}$

\section{Efficacy of inhaled glycopyrrolate combinations}

Combining a LAMA with a LABA can increase efficacy, as they have distinctly different mechanisms of action (ie, target different receptors). In addition, LABAs modify the release of ACh, leading to amplification of bronchial smooth muscle relaxation induced by the LAMA.$^{58}$ Moreover, LABAs act on presynaptic $\beta_{2}$-receptors in the efferent cholinergic pathway, resulting in the inhibition of cholinergic transmission. ${ }^{59}$

In 2016, glycopyrrolate-formoterol pMDI 18/9.6 $\mu \mathrm{g}$ BID was licensed by the FDA "for the long-term maintenance treatment of airflow obstruction in patients with COPD". ${ }^{34}$ Several randomized controlled trials have examined the efficacy of glycopyrrolate-formoterol 18/9.6 $\mu \mathrm{g}$ BID (Table 4) ${ }^{60,61}$ Five studies (PINNACLE-1, PINNACLE-2, PT003011, PT003012, and PINNACLE-3) showed that (as expected) glycopyrrolate-formoterol 18/9.6 $\mu \mathrm{g}$ BID significantly improved lung function compared with individual components and placebo. ${ }^{60-62}$ In addition, glycopyrrolate-formoterol 18/9.6 $\mu \mathrm{g}$ BID was at least as efficacious as open-label tiotropium $18 \mu \mathrm{g}$ QD. ${ }^{61,62}$ Furthermore, the efficacy of glycopyrrolate-formoterol 18/9.6 $\mu \mathrm{g}$ BID was maintained over the 1-year treatment period. ${ }^{60,61}$ A post hoc analysis of PINNACLE-1 and -2 indicated that glycopyrrolate-formoterol improved $\mathrm{FEV}_{1}$ independently of baseline symptom severity, although high baseline symptom severity was significantly correlated with greater improvement in health outcomes after treatment. ${ }^{63}$

Inhaled glycopyrrolate has also been combined with indacaterol for maintenance therapy in patients with COPD. Glycopyrrolate-indacaterol DPI was approved for use by the FDA in 2015 (at 15.6/27.5 $\mu \mathrm{g}$ BID) ${ }^{36}$ and by the EMA in 2013 (at 50/110 $\mu \mathrm{g}$ QD). ${ }^{35}$ Glycopyrrolate-indacaterol 50/110 $\mu \mathrm{g}$ QD significantly improved lung function compared with individual components $(P<0.001)^{64}$ and tiotropium $18 \mu \mathrm{g}$ QD $(P=0.0017) .{ }^{65}$ The glycopyrrolate-indacaterol combination was also preferred to tiotropium by both patients $(P=0.00004)$ and physicians $(P<0.0001) .{ }^{65}$ Furthermore, glycopyrrolate-indacaterol 50/110 $\mu \mathrm{g}$ QD significantly increased lung function, and a significantly greater proportion of patients achieved a clinically relevant improvement in dyspnea compared with tiotropium $18 \mu \mathrm{g}$ QD plus formoterol $12 \mu \mathrm{g}$ BID. ${ }^{66}$ In two clinical trials, glycopyrrolate-indacaterol $50 / 110 \mu \mathrm{g}$ QD was more effective at reducing COPD exacerbations than the ICS-LABA combination fluticasone propionate-salmeterol 500/50 $\mu \mathrm{g}$ BID. ${ }^{67,68}$ Additionally, 
Table 4 Recent clinical evidence (2015 to present) of efficacy of glycopyrrolate combinations in patients with COPD

\begin{tabular}{llll}
\hline Clinical trial & $\begin{array}{l}\text { Treatment } \\
\text { duration }\end{array}$ & Treatments & Key findings \\
\end{tabular}

Glycopyrrolate-formoterol FDC delivered using co-suspension delivery technology via a pMDI

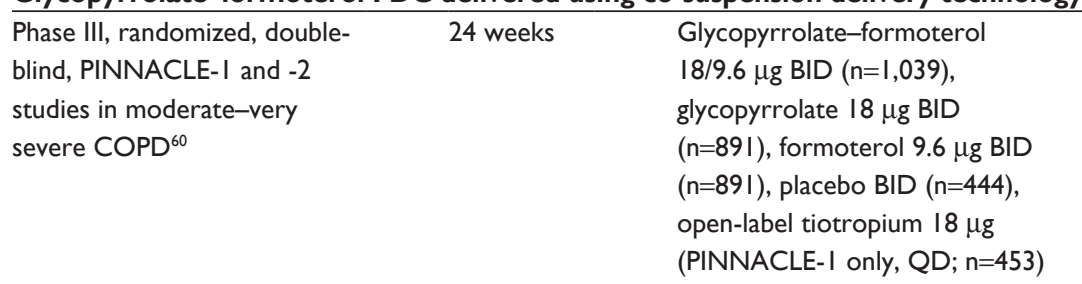

At week 24, the change in predose trough FEV, for glycopyrrolate-formoterol was significantly greater than for glycopyrrolate, formoterol, and placebo (LSM difference in change from baseline vs comparators, PINNACLE-I, 0.059-0.150 L, $P<0.000$ I; PINNACLE-2, 0.054-0.103 L, $P<0.00$ I) Change in predose trough $\mathrm{FEV}_{\text {, for glycopyrrolate- }}$ formoterol did not differ significantly from tiotropium in PINNACLE-I, but did in PINNACLE-2 (LSM difference in change from baseline 0.021 , $P=\mathrm{NS}$ and $0.103, P<0.001$, respectively)

\begin{tabular}{|c|c|c|}
\hline $\begin{array}{l}\text { Phase III, randomized, double- } \\
\text { blind trial (PINNACLE-3 } \\
\text { [a PINNACLE-I and -2 } \\
\text { extension study]) }\end{array}$ & 28 weeks & 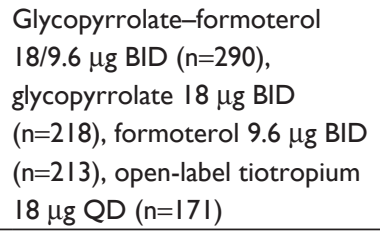 \\
\hline $\begin{array}{l}\text { Two Phase IIIB, double-blind, } \\
\text { crossover studies (PT0030II } \\
\text { and PT0030I2) in moderate- } \\
\text { very severe COPD }{ }^{62}\end{array}$ & 4 weeks & 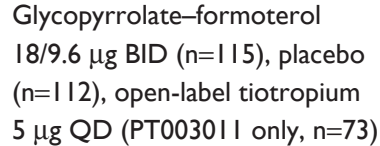 \\
\hline
\end{tabular}

At week 52, the change in predose trough FEV, for glycopyrrolate-formoterol was significantly greater than that for all other treatments (LSM difference in change from baseline $0.025-0.065 \mathrm{~L}, P \leq 0.0$ I I 7)
By day 29, glycopyrrolate-formoterol had significantly improved $\mathrm{FEV}_{1} \mathrm{AUC}_{0-24}$ vs placebo (LSM treatment difference, PT0030I I, 0.265 L; PT0030 I 2, 0.249 L; both $P<0.000$ I) In PT0030I I, glycopyrrolate-formoterol treatment resulted in significantly improved $\mathrm{FEV}_{1} \mathrm{AUC}_{0-12}$ vs tiotropium (LSM treatment difference $0.080 \mathrm{~L}$, $P=0.0001$ )

FEV AUC $_{12-14}$ improvements with glycopyrrolateformoterol were also greater than for placebo (LSM treatment difference for $\mathrm{FEV}_{1} \mathrm{AUC}_{0-12}$, PT0030I I 0.25 I and PT0030I 2 0.255; for $\mathrm{AUC}_{0-24}$, PT0030II 0.277 and PT0030I 2 0.242)

\section{Glycopyrrolate-indacaterol FDC via a DPI}

\begin{tabular}{|c|c|c|c|}
\hline $\begin{array}{l}\text { Randomized, double-blind, } \\
\text { noninferiority FLAME } \\
\text { trial in patients with high- } \\
\text { exacerbation risk }{ }^{67}\end{array}$ & 52 weeks & $\begin{array}{l}\text { Glycopyrrolate-indacaterol } \\
50 / \text { I I0 } \mu \mathrm{g} \text { QD }(n=1,680) \\
\text { fluticasone propionate- } \\
\text { salmeterol } 500 / 50 \mu \mathrm{g} \text { BID } \\
(\mathrm{n}=1,682)\end{array}$ & $\begin{array}{l}\text { The glycopyrrolate-indacaterol combination } \\
\text { was found to be superior to fluticasone } \\
\text { propionate-salmeterol in reducing annual COPD } \\
\text { exacerbations }(P=0.003) \text { and increasing time to } \\
\text { first exacerbation }(P<0.00 \mathrm{I})\end{array}$ \\
\hline $\begin{array}{l}\text { Randomized, double-blind, } \\
\text { LANTERN study in moderate- } \\
\text { severe COPD with a history of } \\
\text { exacerbations }^{68}\end{array}$ & 26 weeks & $\begin{array}{l}\text { Glycopyrrolate-indacaterol } \\
50 / I 10 \mu g \text { QD }(n=372) \\
\text { fluticasone propionate- } \\
\text { salmeterol 500/50 } \mu \mathrm{g} \text { BID } \\
(n=372)\end{array}$ & $\begin{array}{l}\text { At week } 26 \text {, glycopyrrolate-indacaterol was } \\
\text { significantly superior at improving trough } \mathrm{FEV} \text {, to } \\
\text { fluticasone propionate-salmeterol (LSM treatment } \\
\text { difference } 0.075, P<0.00 \mathrm{I} \text { ) } \\
\text { At week } 26 \text {, the glycopyrrolate-indacaterol group } \\
\text { showed a significantly greater improvement in FEV, } \\
\text { AUC }_{0-4} \text { than the fluticasone propionate-salmeterol } \\
\text { group (LSM treatment difference } 0.122 \mathrm{~L}, \mathrm{P}<0.00 \mathrm{I} \text { ) } \\
\text { Glycopyrrolate-indacaterol treatment reduced } \\
\text { moderate/severe exacerbations to a significantly } \\
\text { greater extent than fluticasone propionate- } \\
\text { salmeterol }(P=0.048)\end{array}$ \\
\hline $\begin{array}{l}\text { Post hoc analysis of pooled } \\
\text { ILLUMINATE and LANTERN } \\
\text { trials examining symptomatic } \\
\text { (GOLD B and D) }{ }^{\mathrm{a}} \text { patients with } \\
\text { moderate-severe COPD }{ }^{72}\end{array}$ & 26 weeks & $\begin{array}{l}\text { Glycopyrrolate-indacaterol } \\
50 / I 10 \mu g \text { QD }(n=630) \\
\text { fluticasone propionate- } \\
\text { salmeterol } 500 / 50 \mu g \text { BID } \\
(n=633)\end{array}$ & $\begin{array}{l}\text { At week } 26 \text {, glycopyrrolate-indacaterol significantly } \\
\text { improved lung function from baseline vs fluticasone } \\
\text { propionate-salmeterol in symptomatic patients } \\
\text { (LSM treatment difference in predose trough } \\
\text { FEV, in GOLD B and D patients } 0.10 \text { and } 0.08 \mathrm{~L} \text {, } \\
\text { respectively [both } P<0.000 \text { I]; LSM treatment } \\
\text { difference in FEV, AUC } 0.120 \mathrm{~L}[P<0.000 \mathrm{I}] \text { in } \\
\text { GOLD B and } 0.1 \mathrm{I} L[P<0.005] \text { in GOLD D) }\end{array}$ \\
\hline
\end{tabular}

(Continued) 
Table 4 (Continued)

\begin{tabular}{|c|c|c|}
\hline Clinical trial & $\begin{array}{l}\text { Treatment } \\
\text { duration }\end{array}$ & Treatments \\
\hline $\begin{array}{l}\text { Two randomized, double-blind, } \\
\text { crossover studies (A2349 } \\
\text { and } A 2350 \text { ) in patients with } \\
\text { moderate-severe COPD }{ }^{71}\end{array}$ & 12 weeks & 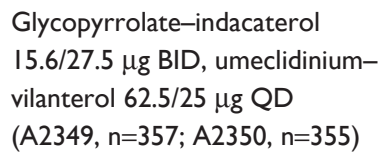 \\
\hline
\end{tabular}

Key findings

Noninferiority of glycopyrrolate-indacaterol vs umeclidinium-vilanterol for change from baseline in $\mathrm{FEV}_{1} \mathrm{AUC}_{0-24}$ at week 12 was not met (lower boundary of $97.5 \%$ one-sided $\mathrm{Cl}$ for glycopyrrolate-indacaterol below prespecified margin of $-20 \mathrm{~mL}$ in both studies; LSM betweentreatment differences $-11.5 \mathrm{~mL}, 95 \% \mathrm{Cl}-26.9$ to 3.8 [A2349] and $-18.2 \mathrm{~mL}, 95 \% \mathrm{Cl}-34.2$ to 2.3 [A2350])

Both glycopyrrolate-indacaterol and umeclidinium-vilanterol improved $\mathrm{FEV}_{1} \mathrm{AUC}_{12-24}$ (208 and $203 \mathrm{~mL}$ [A2349], I63 and I54 mL [A2350]) and trough FEV, levels from baseline at week 12 (I89 and $201 \mathrm{~mL}$ [A2349], 168 and $177 \mathrm{~mL}$ [A2350])

\begin{tabular}{|c|c|c|}
\hline $\begin{array}{l}\text { Randomized, double-blind, } \\
\text { crossover, MOVE study in } \\
\text { patients with moderate-severe } \\
\text { COPD }^{73}\end{array}$ & 21 days & $\begin{array}{l}\text { Glycopyrrolate-indacaterol } \\
50 / 110 \mu \mathrm{g} Q \mathrm{Q} \text {, then placebo; } \\
\text { placebo, then glycopyrrolate- } \\
\text { indacaterol } 50 / 110 \mu \mathrm{g} \text { QD } \\
(\mathrm{n}=194)\end{array}$ \\
\hline $\begin{array}{l}\text { Randomized, multicenter, } \\
\text { blinded, QUANTIFY study in } \\
\text { moderate-severe COPD }\end{array}$ & 26 weeks & $\begin{array}{l}\text { Glycopyrrolate-indacaterol } \\
50 / 110 \mu \mathrm{g} \text { QD }(\mathrm{n}=476), \\
\text { tiotropium I8 } \mu \mathrm{g} \text { QD }+ \\
\text { formoterol I } 2 \mu \mathrm{g} \text { BID }(\mathrm{n}=458)\end{array}$ \\
\hline
\end{tabular}
Glycopyrrolate-indacaterol significantly improved peak IC levels (LSM treatment difference $0.202 \mathrm{~L}$, $P<0.000 \mathrm{I})$ and activity-related energy used $(P=0.040)$ vs placebo after $2 \mathrm{I}$ days' treatment patients with moderate-severe $\mathrm{COPD}^{73}$ $(\mathrm{n}=194)$

\author{
At week 26, glycopyrrolate-indacaterol was found \\ to be noninferior to tiotropium + formoterol \\ in improving SGRQ scores (LSM treatment \\ difference -0.69 ) \\ At week 26, significantly more patients using \\ glycopyrrolate-indacaterol vs tiotropium + \\ formoterol achieved a clinically relevant \\ improvement in TDI score (49.6\% vs $42.4 \%$, \\ $P=0.033)$ and significantly improved predose $\mathrm{FEV}_{1}$ \\ (LSM treatment difference $0.068 \mathrm{~L}, P<0.00 \mathrm{I}$ ) and \\ FVC (LSM treatment difference $0.074 \mathrm{~L}, P<0.0 \mathrm{I}$ )

Glycopyrrolate-indacaterol significantly increased \\ FEV , I hour postdose vs tiotropium after 4 weeks' \\ treatment (treatment difference $0.08 \mathrm{I} L, P=0.00 \mathrm{I}$ )
}

Randomized, open-label,
crossover, FAVOR study in
symptomatic (GOLD B or D)
patients who had previously
received tiotropium therapy ${ }^{65}$

Pooled analysis of randomized,
double-blind, parallel-group,
FLIGHTI and FLIGHT2 studies
in moderate-severe COPD

4 weeks

4 weeks

Open-label glycopyrrolateindacaterol 50/1 $10 \mu \mathrm{g}$ QD, then tiotropium $18 \mu \mathrm{g}$ QD ( $\mathrm{n}=43)$; tiotropium $18 \mu \mathrm{g} \mathrm{QD}$, then open-label glycopyrrolateindacaterol 50/1 $10 \mu \mathrm{g}$ QD $(\mathrm{n}=45)$
Glycopyrrolate-indacaterol 15.6/27.5 $\mu \mathrm{g}$ BID ( $n=260)$, indacaterol $27.5 \mu \mathrm{g}$ BID $(n=260)$, glycopyrrolate $15.6 \mu \mathrm{g}$ $\operatorname{BID}(n=26 \mathrm{I})$, placebo $(n=26 \mathrm{I})$

$\begin{array}{ll}\text { I2 weeks } & \text { Glycopyrrolate-indacaterol } \\ & \text { I5.6/27.5 } \mu \mathrm{g} \text { BID }(\mathrm{n}=260), \\ & \text { indacaterol } 27.5 \mu \mathrm{g} \text { BID } \\ & (\mathrm{n}=260), \text { glycopyrrolate } 15.6 \mu \mathrm{g} \\ & \text { BID }(\mathrm{n}=26 \mathrm{I}), \text { placebo }(\mathrm{n}=26 \mathrm{I})\end{array}$

\author{
Glycopyrrolate-indacaterol improved FEV, \\ $\mathrm{AUC}_{0-12}$ significantly more than individual \\ components (LSM treatment difference $0.103 \mathrm{~L}$ vs \\ indacaterol and $0.088 \mathrm{~L}$ vs glycopyrrolate, \\ respectively; both $P<0.00 \mathrm{I}$ ) and placebo (LSM \\ treatment difference $0.246 \mathrm{~L}, P<0.00 \mathrm{I}$ ) \\ Compared with individual components and \\ placebo, glycopyrrolate-indacaterol produced \\ significantly greater and more clinically \\ meaningful improvements in TDI total score \\ (LSM treatment difference 0.78 points vs \\ indacaterol, 0.73 points vs glycopyrrolate, and \\ I.64 points vs placebo; all $P<0.00 \mathrm{I}$ ) and SGRQ \\ score (LSM treatment difference -1.7 points \\ vs indacaterol $[P<0.05],-1.5$ points vs \\ glycopyrrolate $[P<0.05],-5.0$ points vs placebo \\ $[P<0.00$ I $])$
}


Table 4 (Continued)

\begin{tabular}{|c|c|c|c|}
\hline Clinical trial & $\begin{array}{l}\text { Treatment } \\
\text { duration }\end{array}$ & Treatments & Key findings \\
\hline $\begin{array}{l}\text { Randomized, multicenter, } \\
\text { double-blind, parallel-group, } \\
\text { FLIGHT3 study in moderate- } \\
\text { severe COPD }\end{array}$ & 52 weeks & $\begin{array}{l}\text { Glycopyrrolate-indacaterol } \\
\text { I5.6/27.5 } \mu \mathrm{g} \text { BID }(\mathrm{n}=204), \\
\text { glycopyrrolate-indacaterol } \\
31.2 / 27.5 \mu \mathrm{g} \text { BID }(\mathrm{n}=204), \\
\text { indacaterol } 75 \mu \mathrm{gD}(\mathrm{n}=207)\end{array}$ & $\begin{array}{l}\text { Improvements in predose trough FEV, were } \\
\text { greater with glycopyrrolate-indacaterol } \\
\text { I5.6/27.5 } \mu \mathrm{g} \text { and } 3 \mathrm{I} .2 / 27.5 \mu \mathrm{g} \text { (LSM treatment } \\
\text { difference } 0.080 \mathrm{~L} \text { and } 0.079 \mathrm{~L} \text {, respectively), } \\
\text { and improvements in I-hour postdose } \mathrm{FEV} \text {, } \\
\text { were greater with glycopyrrolate-indacaterol } \\
\text { I5.6/27.5 } \mu \mathrm{g} \text { (LSM treatment difference } 0.108 \mathrm{~L} \text { ) } \\
\text { than indacaterol alone at week } 52\end{array}$ \\
\hline
\end{tabular}

\section{Glycopyrrolate via DPI plus FDC fluticasone propionate-salmeterol via DPI}

Randomized, blinded, GLISTEN 12 weeks Glycopyrrolate $50 \mu \mathrm{g}$ QD +
study in moderate-severe fluticasone propionateCOPD $^{74}$

\section{salmeterol 500/50 $\mu \mathrm{g}$ BID} $(\mathrm{n}=258)$, tiotropium $18 \mu \mathrm{g}$ QD + fluticasone propionatesalmeterol 500/50 $\mu \mathrm{g}$ BID $(n=258)$, placebo + fluticasone propionate-salmeterol

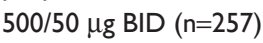

\begin{abstract}
At week 12, glycopyrrolate + fluticasone propionate-salmeterol significantly improved trough FEV, from baseline vs placebo + fluticasone propionate-salmeterol (LSM treatment difference $0.10 \mathrm{I}$ L, $P<0.00 \mathrm{I}$ )

At week 12, glycopyrrolate + fluticasone propionate-salmeterol was noninferior to tiotropium + fluticasone propionate-salmeterol (LSM treatment difference $-0.007 \mathrm{~L}$ ) At week 12, glycopyrrolate + fluticasone propionate-salmeterol significantly improved SGRQ total scores from baseline vs placebo + fluticasone propionate-salmeterol (LSM treatment difference $-2.15, P=0.02$ )
\end{abstract}

\title{
Extrafine glycopyrrolate-beclomethasone-formoterol FDC via pMDI
}

Randomized, double-blind, 52 weeks 2-week open-label run-in active-comparator, TRILOGY period, beclomethasonestudy in patients with symptomatic COPD ${ }^{75}$ formoterol 100/6 $\mu$ g; patients then randomly assigned to beclomethasone-formoterol 100/6 $\mu \mathrm{g}(\mathrm{n}=68 \mathrm{I})$ or stepped up to glycopyrrolatebeclomethasone-formoterol I2.5/100/6 $\mu \mathrm{g}(\mathrm{n}=687)$

Randomized, double-blind, $\quad 52$ weeks 2-week open-label tiotropium
TRINITY study in patients with symptomatic COPD ${ }^{76}$ 2-week open-label tiotropium
I8 $\mu \mathrm{g}$ QD, then open-label tiotropium $\mu \mathrm{g}$ QD $(n=I, 075)$, glycopyrrolatebeclomethasone-formoterol 12.5/100/6 $\mu \mathrm{g} \operatorname{BID}(\mathrm{n}=1,078)$, beclomethasone-formoterol 100/6 $\mu \mathrm{g}$ BID + tiotropium $18 \mu \mathrm{g}$ QD $(\mathrm{n}=538)$
At week 26, triple FDC significantly improved predose (treatment difference $0.08 \mathrm{I} \mathrm{L}$ ) and 2-hour postdose FEV (treatment difference $0.117 \mathrm{~L}$ ) from baseline vs the dual ICS-LABA (both $P<0.001$ )

At week 52, patients in the triple FDC group experienced $23 \%$ fewer moderate/severe exacerbations than those in the dual ICS-LABA FDC group

Glycopyrrolate-beclomethasone-formoterol was superior to tiotropium in reducing the rate of exacerbations $(P=0.0025)$ and week 52 predose $\mathrm{FEV}_{1}$ (treatment difference $0.06 \mathrm{I} \mathrm{L}, P<0.000 \mathrm{I}$ ) Glycopyrrolate-beclomethasone-formoterol had a similar efficacy to beclomethasone-formoterol + tiotropium in terms of risk of exacerbations $(P=0.890)$ and was noninferior for improvement in predose $F E V$, at week 52 (treatment difference $-0.003 \mathrm{~L}, P=0.85$ )

Note: aGOLD B and D defined according to the 2013 GOLD guidelines (FAVOR), the 2010 GOLD guidelines (ILLUMINATE), or the 2009 GOLD guidelines (LANTERN). Abbreviations: AUC, area under curve; BID, bis in die (twice daily); DPI, dry-powder inhaler; FDC, fixed-dose combination; FEV , forced expiratory volume in I second; FVC, forced vital capacity; GOLD, Global Initiative for Chronic Obstructive Pulmonary Disease; LSM, least squares mean; IC, inspiratory capacity; ICS-LABA, inhaled corticosteroid-long-acting $\beta 2$-agonist; NS, not significant; PMDI, pressurized metered-dose inhaler; QD, quaque die (once daily); SGRQ, St George's Respiratory Questionnaire; TDI, Transition Dyspnea Index.

glycopyrrolate-indacaterol 50/110 $\mu \mathrm{g}$ QD was found to be noninferior to tiotropium $18 \mu \mathrm{g}$ QD plus formoterol $12 \mu \mathrm{g}$ BID in improving HRQoL. ${ }^{66}$

The 15.6/27.5 $\mu \mathrm{g}$ BID formulation of glycopyrrolateindacaterol DPI has been shown to perform favorably in improving lung function when compared with its individual components ${ }^{69,70}$ and provide clinically meaningful improvements in breathlessness and HRQoL. ${ }^{69}$ Two crossover studies of glycopyrrolate-indacaterol 15.6/27.5 $\mu \mathrm{g}$ BID vs umeclidinium-vilanterol 62.5/25 $\mu \mathrm{g}$ QD did not meet their primary efficacy end point of noninferiority of change from baseline in $\mathrm{FEV}_{1}$ area under the curve from 0 to 24 hours at week 12. 
The authors concluded that although glycopyrrolate-indacaterol was not non-inferior to umeclidinium-vilanterol, the differences in improvement in lung function between the combinations were not clinically relevant. ${ }^{71}$ Several clinical trials have indicated that glycopyrrolate-indacaterol is effective at improving lung function in patients with moderate-severe COPD, ${ }^{68,69,71-73}$ and patients with COPD and a high risk of exacerbations. ${ }^{67}$ One of these trials also demonstrated that glycopyrrolate-indacaterol decreases hyperinflation and improves patients' ability to undertake daily physical activity. ${ }^{73}$

Glycopyrrolate also showed potential as a COPD treatment when added to the ICS-LABA combination fluticasone propionate-salmeterol. ${ }^{74}$ After 12 weeks' treatment, glycopyrrolate $50 \mu \mathrm{g}$ QD plus fluticasone propionatesalmeterol 500/50 $\mu \mathrm{g}$ BID significantly improved lung function when compared with placebo plus fluticasone propionate-salmeterol, and was noninferior to tiotropium (18 $\mu \mathrm{g}$ QD) plus fluticasone propionate-salmeterol. ${ }^{74}$

An inhaled triple FDC, glycopyrrolate-beclomethasoneformoterol (12.5/100/6 $\mu \mathrm{g}$ BID pMDI) was approved for use by the EMA in 2017 for the maintenance treatment of patients with COPD. ${ }^{39}$ Two long-term trials have demonstrated that this triple FDC is efficacious in this patient group. ${ }^{75,76}$ In the first trial, the triple FDC was significantly more effective at improving lung function vs beclomethasoneformoterol at week $26 .{ }^{75}$ The triple FDC also decreased the risk of exacerbations from baseline to a greater extent than beclomethasone-formoterol by week $52 .{ }^{75}$ The second trial provided evidence that this triple FDC was significantly superior to tiotropium in reducing the exacerbation rate and improving lung function from baseline. ${ }^{76}$

\section{Safety of inhaled glycopyrrolate monotherapy}

Several trials have shown that glycopyrrolate $50 \mu \mathrm{g}$ QD DPI is well tolerated, ${ }^{41-47}$ with a similar overall incidence of AEs to tiotropium $18 \mu \mathrm{g}$ QD. ${ }^{42,44,45,47}$ In a study comparing glycopyrrolate $50 \mu \mathrm{g}$ QD with open-label tiotropium $18 \mu \mathrm{g}$ QD, the incidences of AEs and serious AEs were similar between groups; AEs with incidence $>10 \%$ were worsening COPD (24\% [glycopyrrolate] vs 33\% [tiotropium]) and nasopharyngitis (31\% vs 33\%, respectively). ${ }^{44}$ Glycopyrrolate also had an acceptable safety profile at $15.6 \mu \mathrm{g}$ BID,${ }^{48-50}$ with AE incidence after 52 weeks' treatment similar to that seen after treatment with indacaterol $75 \mu \mathrm{g}$ QD. ${ }^{50}$ Furthermore, nebulized glycopyrrolate (50 $\mu \mathrm{g}$ BID) was also shown to have an acceptable safety profile over 48 weeks' treatment compared with tiotropium $18 \mu \mathrm{g}$ QD. ${ }^{51}$ Treatment discontinuation due to treatment-emergent AEs was higher for nebulized glycopyrrolate than for tiotropium (10\% vs 3\%, respectively); the authors suggested several reasons for this, including the open-label nature of the trial. ${ }^{51}$ In another study, nebulized glycopyrrolate was well tolerated at 25 and $50 \mu \mathrm{g}$ BID, as measured by the incidences of AEs and cardiovascular (CV) events. ${ }^{38}$ Finally, in two chronic-dosing trials of glycopyrrolate pMDI delivered using co-suspension delivery technology, glycopyrrolate had an acceptable safety profile at all doses evaluated, with no unexpected safety findings reported. ${ }^{52,57}$

Newly prescribed LAMAs and LABAs have been associated with a greater risk of $\mathrm{CV}$ events compared with nonuse in patients with COPD (adjusted OR 1.14 [95\% CI 1.01-1.28, $P=0.03]$ and 1.31 [95\% CI 1.12-1.52, $P<0.001]$ for LAMAs and LABAs, respectively). ${ }^{77}$ However, the studies discussed in this review provide no evidence for an increased risk of $\mathrm{CV}$ events with glycopyrrolate monotherapy vs tiotropium or indacaterol monotherapy. ${ }^{45,50}$ Furthermore, in one of the trials investigating nebulized glycopyrrolate, fewer patients treated with glycopyrrolate experienced major CV AEs than those treated with tiotropium $(0.5 \%$ vs $1.7 \%) .^{51}$

\section{Safety of inhaled glycopyrrolate combinations}

The FDC glycopyrrolate-formoterol is designed to minimize the risk of AEs associated with high doses of LAMA or LABA monotherapies. In its Phase III clinical development program, glycopyrrolate-formoterol pMDI 18/9.6 $\mu \mathrm{g}$ BID showed a safety profile consistent with that of the individual components (PINNACLE-1 and -2), placebo (PINNACLE-1 and -2, PT003011, and PT003012), and open-label tiotropium $18 \mu \mathrm{g}$ QD (PINNACLE-1 and PT003011). ${ }^{60-62}$

Furthermore, several clinical trials have indicated that the glycopyrrolate-indacaterol DPI combination at both EMA- and FDA-approved doses (50/110 $\mu \mathrm{g}$ QD and 15.6/27.5 $\mu \mathrm{g}$ QD, respectively) has good tolerability and an acceptable safety profile in patients with moderate-severe COPD. ${ }^{65,67-69,71-73}$ A trial by Ferguson et al showed that the risk of CV events was similar with the glycopyrrolate-indacaterol FDC to with indacaterol alone. ${ }^{70}$

Safety end points have also been assessed in triple FDC therapy regimens that incorporate glycopyrrolate. For example, in a study comparing glycopyrrolate plus fluticasone propionate-salmeterol with the ICS-LABA combination administered with either tiotropium $18 \mu \mathrm{g}$ QD or placebo, the authors reported no significant differences 
between the number of AEs or severe AEs in any of the treatment groups evaluated. ${ }^{74}$ In a study comparing the glycopyrrolate-beclomethasone-formoterol FDC with both tiotropium and beclomethasone-formoterol plus tiotropium, AE incidence was similar among treatment groups. ${ }^{76}$ A further study comparing glycopyrrolate-beclomethasoneformoterol with beclomethasone-formoterol also reported similar rates of AEs between treatment groups, although one serious treatment-emergent AE (atrial fibrillation) occurred in a patient from the triple-FDC group. ${ }^{75}$

\section{Conclusion}

Inhaled glycopyrrolate is a fast-acting, efficacious treatment option for patients with moderate-severe COPD and is available in a variety of doses. It improves lung function, reduces the risk of exacerbations, and alleviates the symptoms of breathlessness, which in turn may explain the improvement seen in patients' QoL. Glycopyrrolate has comparable effects on lung function to tiotropium, and glycopyrrolate and aclidinium showed more rapid onset of action than tiotropium. Formulations containing inhaled glycopyrrolate are well tolerated and, despite being an anticholinergic, few CV-related events have been reported, with glycopyrrolate showing a similar safety profile to tiotropium. Inhaled glycopyrrolate is thus of value both as monotherapy and for optimizing bronchodilation when used in FDCs with LABAs and ICS-LABAs for maintenance treatment of COPD.

\section{Acknowledgments}

We thank Johan Karlberg, MD, PhD, of the Clinical Trial Magnifier Newsletter for some of the information in this manuscript. Medical writing support was provided by Carly Hayes, PhD, of Core (London, UK) and editorial support was provided by Maryam Vahdat, PGDip of Core (London, UK), which was in accordance with Good Publication Practice (GPP3) guidelines and funded by AstraZeneca LP (Wilmington, DE, USA). AstraZeneca LP reviewed the manuscript for medical accuracy prior to submission.

\section{Author contributions}

DPT and NJG made substantial contributions to the conception of this article, drafted, and critically revised it for important intellectual content; provided final approval of the version to be published; and agreed to be accountable for all aspects of the work in ensuring that questions related to the accuracy or integrity of the work are appropriately investigated and resolved.

\section{Disclosure}

DPT serves on advisory boards for AstraZeneca, Sunovion, Mylan, and Theravance/Innoviva, and as a speaker for AstraZeneca, Boehringer-Ingelheim, and Sunovion. NJG has no conflicts of interest.

\section{References}

1. Global Initiative for Chronic Obstructive Lung Disease (GOLD). Global Strategy for the Diagnosis, Management and Prevention of Chronic Obstructive Pulmonary Disease. Bethesda, MD: GOLD; 2017.

2. Qaseem A, Wilt TJ, Weinberger SE, et al. Diagnosis and management of stable chronic obstructive pulmonary disease: a clinical practice guideline update from the American College of Physicians, American College of Chest Physicians, American Thoracic Society, and European Respiratory Society. Ann Intern Med. 2011;155(3):179-191.

3. Schroeckenstein DC, Bush RK, Chervinsky P, Busse WW. Twelve-hour bronchodilation in asthma with a single aerosol dose of the anticholinergic compound glycopyrrolate. J Allergy Clin Immunol. 1988;82(1):115-119.

4. Walker FB, Kaiser DL, Kowal MB, Suratt PM. Prolonged effect of inhaled glycopyrrolate in asthma. Chest. 1987;91(1):49-51.

5. Johnson BE, Suratt PM, Gal TJ, Wilhoit SC. Effect of inhaled glycopyrrolate and atropine in asthma: precipitated by exercise and cold air inhalation. Chest. 1984;85(3):325-328.

6. US Food and Drug Administration. Seebri Neohaler [prescribing Information]. 2015. Available from: https://www.accessdata.fda.gov/ drugsatfda_docs/label/2015/207923lbl.pdf. Accessed March 20, 2018.

7. European Medicines Agency. European public assessment report: Seebri Breezhaler. 2012. Available from: http://www.ema.europa.eu/ docs/en_GB/document_library/EPAR_-_Public_assessment_report/ human/002430/WC500133771.pdf. Accessed March 20, 2018.

8. Cazzola M, Page CP, Calzetta L, Matera MG. Pharmacology and therapeutics of bronchodilators. Pharmacol Rev. 2012;64(3):450-504.

9. Racké K, Matthiesen S. The airway cholinergic system: physiology and pharmacology. Pulm Pharmacol Ther. 2004;17(4):181-198.

10. Franko BV, Lunsford CD. Derivatives of 3-pyrrolidinols - III: the chemistry, pharmacology, and toxicology of some $\mathrm{N}$-substituted-3-pyrrolidyl $\alpha$-substituted phenylacetates. J Med Pharm Chem. 1960;2:523-540.

11. Barnes PJ. Anticholinergics. In: Celli BR, editor. Pharmacotherapy in Chronic Obstructive Pulmonary Disease. New York: Marcel Dekker; 2004:201-216.

12. Bartels C, Looby M, Sechaud R, Kaiser G. Determination of the pharmacokinetics of glycopyrronium in the lung using a population pharmacokinetic modelling approach. Br J Clin Pharmacol. 2013;76(6): 868-879.

13. Sykes DA, Dowling MR, Leighton-Davies J, et al. The influence of receptor kinetics on the onset and duration of action and the therapeutic index of NVA237 and tiotropium. J Pharmacol Exp Ther. 2012;343(2): 520-528.

14. Kaltiala E, Penttilä A, Vapaatalo H, Larmi T. The fate of intravenous $\left({ }^{3} \mathrm{H}\right)$ glycopyrrolate in man. J Pharm Pharmacol. 1974;26(5):352-354.

15. Sechaud R, Renard D, Zhang-Auberson L, de la Motte S, Drollmann A, Kaiser G. Pharmacokinetics of multiple inhaled NVA237 doses in patients with chronic obstructive pulmonary disease (COPD). Int $J$ Clin Pharmacol Ther. 2012;50(2):118-128.

16. Gavaldà $\mathrm{A}$, Ramos I, Carcasona $\mathrm{C}$, et al. The in vitro and in vivo profile of aclidinium bromide in comparison with glycopyrronium bromide. Pulm Pharmacol Ther. 2014;28(2):114-121.

17. Hansel TT, Barnes PJ. Tiotropium bromide: a novel once-daily anticholinergic bronchodilator for the treatment of COPD. Drugs Today (Barc). 2002;38(9):585-600.

18. Ogoda M, Niiya R, Koshika T, Yamada S. Comparative characterization of lung muscarinic receptor binding after intratracheal administration of tiotropium, ipratropium, and glycopyrrolate. J Pharmacol Sci. 2011; 115(3):374-382. 
19. Rogliani P, Calzetta L, Ora J, et al. Pharmacological assessment of the onset of action of aclidinium and glycopyrronium versus tiotropium in COPD patients and human isolated bronchi. Eur J Pharmacol. 2015;761: 383-390.

20. Sentellas S, Ramos I, Alberti J, et al. Aclidinium bromide, a new, longacting, inhaled muscarinic antagonist: in vitro plasma inactivation and pharmacological activity of its main metabolites. Eur J Pharm Sci. 2010; 39(5):283-290.

21. Ramos FL, Krahnke JS, Kim V. Clinical issues of mucus accumulation in COPD. Int J Chron Obstruct Pulmon Dis. 2014;9:139-150.

22. Gosens R, Zaagsma J, Meurs H, Halayko AJ. Muscarinic receptor signaling in the pathophysiology of asthma and COPD. Respir Res. 2006;7:73.

23. Melloni B, Germouty J. [The influence of a new $\beta$-agonist: formoterol on mucociliary function]. Rev Mal Respir. 1992;9(5):503-507. French.

24. Lindberg S, Khan R, Runer T. The effects of formoterol, a long-acting $\beta_{2}$-adrenoceptor agonist, on mucociliary activity. Eur J Pharmacol. 1995; 285(3):275-280

25. Restrepo RD. Inhaled adrenergics and anticholinergics in obstructive lung disease: do they enhance mucociliary clearance? Respir Care. 2007; 52(9):1159-1173.

26. Tagaya E, Yagi O, Sato A, et al. Effect of tiotropium on mucus hypersecretion and airway clearance in patients with COPD. Pulm Pharmacol Ther. 2016;39:81-84.

27. Hasani A, Toms N, Agnew JE, Sarno M, Harrison AJ, Dilworth P. The effect of inhaled tiotropium bromide on lung mucociliary clearance in patients with COPD. Chest. 2004;125(5):1726-1734.

28. Meyer T, Reitmeir P, Brand P, et al. Effects of formoterol and tiotropium bromide on mucus clearance in patients with COPD. Respir Med. 2011;105(6):900-906.

29. Bennett WD, Chapman WF, Mascarella JM. The acute effect of ipratropium bromide bronchodilator therapy on cough clearance in COPD. Chest. 1993;103(2):488-495.

30. Hugel H, Ellershaw J, Gambles M. Respiratory tract secretions in the dying patient: a comparison between glycopyrronium and hyoscine hydrobromide. J Palliat Med. 2006;9(2):279-284.

31. US Food and Drug Administration. Medical review: glycopyrrolate. 2009. Available from: https:/www.accessdata.fda.gov/drugsatfda_docs/ nda/2010/022571Orig1s000MedR.pdf. Accessed March 20, 2018.

32. Mirakhur RK, Dundee JW, Jones CJ. Evaluation of the anticholinergic actions of glycopyrronium bromide. Br J Clin Pharmacol. 1978;5(1): 77-84.

33. European Medicines Agency. Seebri Breezhaler [summary of product characteristics]. 2012. Available from: https://www.medicines.org.uk/ emc/medicine/27138. Accessed March 20, 2018.

34. AstraZeneca Pharmaceuticals LP. Bevespi Aerosphere [prescribing information]. 2016. Available from: https:/www.azpicentral.com/ bevespi/bevespi_pi.pdf. Accessed March 20, 2018.

35. European Medicines Agency. Ultibro Breezhaler [summary of product characteristics]. 2016. Available from: https://www.medicines.org.uk/ emc/medicine/29533. Accessed March 20, 2018.

36. US Food and Drug Administration. Utibron Neohaler [prescribing information]. 2017. Available from: https:/www.accessdata.fda.gov/drugsatfda_docs/label/2015/207930s000lbl.pdf. Accessed March 20, 2018.

37. European Medicines Agency. Trimbow [summary of product characteristics]. 2017. Available from: http://www.ema.europa.eu/docs/en_GB/ document_library/EPAR_-_Product_Information/human/004257/ WC500233163.pdf. Accessed March 20, 2018.

38. Kerwin E, Donohue JF, Goodin T, Tosiello R, Wheeler A, Ferguson GT. Efficacy and safety of glycopyrrolate/eFlow CS (nebulized glycopyrrolate) in moderate-to-very-severe COPD: Results from the glycopyrrolate for obstructive lung disease via electronic nebulizer (GOLDEN) 3 and 4 randomized controlled trials. Respir Med. 2017;132: 238-250.

39. European Medicines Agency. Trimbow [initial authorization]. 2017. Available from: http://www.ema.europa.eu/docs/en_GB/document_ library/Summary_of_opinion_-_Initial_authorisation/human/004257/ WC500228080.pdf. Accessed March 20, 2018.
40. Arievich H, Overend T, Renard D, et al. A novel model-based approach for dose determination of glycopyrronium bromide in COPD. BMC Pulm Med. 2012;12:74.

41. D’Urzo A, Ferguson GT, van Noord JA, et al. Efficacy and safety of once-daily NVA237 in patients with moderate-to-severe COPD: the GLOW1 trial. Respir Res. 2011;12:156.

42. Kerwin E, Hébert J, Gallagher N, et al. Efficacy and safety of NVA237 versus placebo and tiotropium in patients with COPD: the GLOW2 study. Eur Respir J. 2012;40(5):1106-1114.

43. Beeh KM, Singh D, Di Scala L, Drollmann A. Once-daily NVA237 improves exercise tolerance from the first dose in patients with COPD: the GLOW3 trial. Int J Chron Obstruct Pulmon Dis. 2012;7:503-513.

44. Sekiya M, Kawayama T, Fukuchi Y, et al. Safety and efficacy of NVA237 once daily in Japanese patients: the GLOW4 trial. Eur Respir J. 2012;40 (Suppl 56):P2013.

45. Chapman KR, Beeh KM, Beier J, et al. A blinded evaluation of the efficacy and safety of glycopyrronium, a once-daily long-acting muscarinic antagonist, versus tiotropium, in patients with COPD: the GLOW5 study. BMC Pulm Med. 2014;14:4

46. Wang C, Sun T, Huang Y, et al. Efficacy and safety of once-daily glycopyrronium in predominantly Chinese patients with moderateto-severe chronic obstructive pulmonary disease: the GLOW7 study. Int J Chron Obstruct Pulmon Dis. 2015;10:57-68.

47. Marin JM, Beeh KM, Clemens A, et al. Early bronchodilator action of glycopyrronium versus tiotropium in moderate-to-severe COPD patients: a cross-over blinded randomized study (Symptoms and Pulmonary Function in the Morning). Int J Chron Obstruct Pulmon Dis. 2016;11:1425-1434.

48. LaForce C, Feldman G, Spangenthal S, et al. Efficacy and safety of twice-daily glycopyrrolate in patients with stable, symptomatic COPD with moderate-to-severe airflow limitation: the GEM1 study. Int J Chron Obstruct Pulmon Dis. 2016;11:1233-1243.

49. Kerwin E, Siler TM, Korenblat P, et al. Efficacy and safety of twicedaily glycopyrrolate versus placebo in patients with COPD: the GEM2 study. Chronic Obstr Pulm Dis. 2016;3(2):549-559.

50. Mahler DA, Gifford AH, Satti A, et al. Long-term safety of glycopyrrolate: a randomized study in patients with moderate-to-severe COPD (GEM3). Respir Med. 2016;115:39-45.

51. Ferguson GT, Goodin T, Tosiello R, Wheeler A, Kerwin E. Longterm safety of glycopyrrolate/eFlow CS in moderate-to-very-severe COPD: results from the Glycopyrrolate for Obstructive Lung Disease via Electronic Nebulizer (GOLDEN) 5 randomized study. Respir Med. 2017;132:251-260.

52. Fabbri LM, Kerwin EM, Spangenthal S, et al. Dose-response to inhaled glycopyrrolate delivered with a novel Co-Suspension Delivery Technology metered dose inhaler (MDI) in patients with moderate-to-severe COPD. Respir Res. 2016;17(1):109.

53. Karabis A, Lindner L, Mocarski M, Huisman E, Greening A. Comparative efficacy of aclidinium versus glycopyrronium and tiotropium, as maintenance treatment of moderate to severe COPD patients: a systematic review and network meta-analysis. Int J Chron Obstruct Pulmon Dis. 2013;8:405-423.

54. Ismaila AS, Huisman EL, Punekar YS, Karabis A. Comparative efficacy of long-acting muscarinic antagonist monotherapies in COPD: a systematic review and network meta-analysis. Int J Chron Obstruct Pulmon Dis. 2015;10:2495-2517.

55. Lechuga-Ballesteros D, Noga B, Vehring R, Cummings RH, Dwivedi SK. Novel cosuspension metered-dose inhalers for the combination therapy of chronic obstructive pulmonary disease and asthma. Future Med Chem. 2011;3(13):1703-1718.

56. Vehring R, Lechuga-Ballesteros D, Joshi V, Noga B, Dwivedi SK. Cosuspensions of microcrystals and engineered microparticles for uniform and efficient delivery of respiratory therapeutics from pressurized metered dose inhalers. Langmuir. 2012;28(42):15015-15023.

57. Kerwin EM, Spangenthal S, Kollar C, St Rose E, Reisner C. A phase IIB randomized, chronic-dosing, incomplete block, cross-over study of glycopyrronium, delivered via metered dose inhaler, compared with a placebo and an active control in patients with moderate-to-severe COPD. Respir Res. 2018;19(1):38. 
58. Cazzola M, Matera MG. The effective treatment of COPD: anticholinergics and what else? Drug Discov Today Ther Strateg. 2006;3(3): 277-286

59. Barisione G, Baroffio M, Crimi E, Brusasco V. Beta-adrenergic agonists. Pharmaceuticals (Basel). 2010;3(4):1016-1044.

60. Martinez FJ, Rabe KF, Ferguson GT, et al. Efficacy and safety of glycopyrrolate/formoterol metered dose inhaler formulated using Co-Suspension Delivery Technology in patients with COPD. Chest. 2017; 151(2):340-357.

61. Hanania NA, Tashkin DP, Kerwin EM, et al. Long-term safety and efficacy of glycopyrrolate/formoterol metered dose inhaler using novel Co-Suspension Delivery Technology in patients with chronic obstructive pulmonary disease. Respir Med. 2017;126:105-115.

62. Reisner C, Gottschlich G, Fakih F, et al. 24-h bronchodilation and inspiratory capacity improvements with glycopyrrolate/formoterol fumarate via co-suspension delivery technology in COPD. Respir Res. 2017;18:157.

63. Martinez FJ, Fabbri LM, Ferguson GT, et al. Baseline symptom score impact on benefits of glycopyrrolate/formoterol metered dose inhaler in COPD. Chest. 2017;152(6):1169-1178.

64. Bateman ED, Ferguson GT, Barnes N, et al. Dual bronchodilation with QVA149 versus single bronchodilator therapy: the SHINE study. Eur Respir J. 2013;42(6):1484-1494.

65. Kardos P, Hagedorn-Peinz I. The impact of indacaterol/glycopyrronium fixed-dose combination versus tiotropium monotherapy on lung function and treatment preference: a randomized crossover study: the FAVOR study. Int J Chron Obstruct Pulmon Dis. 2018;13:69-77.

66. Buhl R, Gessner C, Schuermann W, et al. Efficacy and safety of once-daily QVA149 compared with the free combination of once-daily tiotropium plus twice-daily formoterol in patients with moderate-to-severe COPD (QUANTIFY): a randomised, non-inferiority study. Thorax. 2015; 70(4):311-319.

67. Wedzicha JA, Banerji D, Chapman KR, et al. Indacaterol-glycopyrronium versus salmeterol-fluticasone for COPD. $N$ Engl J Med. 2016; 374(23):2222-2234.

68. Zhong N, Wang C, Zhou X, et al. LANTERN: a randomized study of QVA149 versus salmeterol/fluticasone combination in patients with COPD. Int J Chron Obstruct Pulmon Dis. 2015;10:1015-1026.

69. Mahler DA, Kerwin E, Ayers T, et al. FLIGHT1 and FLIGHT2: efficacy and safety of QVA149 (indacaterol/glycopyrrolate) versus its monocomponents and placebo in patients with chronic obstructive pulmonary disease. Am J Respir Crit Care Med. 2015;192(9):1068-1079.

70. Ferguson GT, Taylor AF, Thach C, et al. Long-term maintenance bronchodilation with indacaterol/glycopyrrolate versus indacaterol in moderate-to-severe COPD patients: the FLIGHT 3 study. Chronic Obstr Pulm Dis. 2016;3(4):716-728.

71. Kerwin E, Ferguson GT, Sanjar S, et al. Dual bronchodilation with indacaterol maleate/glycopyrronium bromide compared with umeclidinium bromide/vilanterol in patients with moderate-to-severe COPD: results from two randomized, controlled, cross-over studies. Lung. 2017;195(6):739-747.

72. Vogelmeier C,Zhong N, Humphries MJ, et al. Indacaterol/glycopyrronium in symptomatic patients with COPD (GOLD B and GOLD D) versus salmeterol/fluticasone: ILLUMINATE/LANTERN pooled analysis. Int J Chron Obstruct Pulmon Dis. 2016;11:3189-3197.

73. Watz H, Mailänder C, Baier M, Kirsten A. Effects of indacaterol/ glycopyrronium (QVA149) on lung hyperinflation and physical activity in patients with moderate to severe COPD: a randomised, placebocontrolled, crossover study (the MOVE study). BMC Pulm Med. 2016;16(1):95.

74. Frith PA, Thompson PJ, Ratnavadivel R, et al. Glycopyrronium oncedaily significantly improves lung function and health status when combined with salmeterol/fluticasone in patients with COPD: the GLISTEN study, a randomised controlled trial. Thorax. 2015;70(6):519-527.

75. Singh D, Papi A, Corradi M, et al. Single inhaler triple therapy versus inhaled corticosteroid plus long-acting $\beta_{2}$-agonist therapy for chronic obstructive pulmonary disease (TRILOGY): a double-blind, parallel group, randomised controlled trial. Lancet. 2016;388(10048): 963-973.
76. Vestbo J, Papi A, Corradi M, et al. Single inhaler extrafine triple therapy versus long-acting muscarinic antagonist therapy for chronic obstructive pulmonary disease (TRINITY): a double-blind, parallel group, randomised controlled trial. Lancet. 2017;389(10082):1919-1929.

77. Gershon A, Croxford R, Calzavara A, et al. Cardiovascular safety of inhaled long-acting bronchodilators in individuals with chronic obstructive pulmonary disease. JAMA Intern Med. 2013;173(13):1175-1185.

78. US Food and Drug Administration. Lonhala Magnair [prescribing information]. 2017. Available from: https://www.accessdata.fda. gov/drugsatfda_docs/label/2017/2084371bl.pdf. Accessed March 20, 2018.

79. Boehringer Ingelheim. Spiriva HandiHaler [prescribing information]. 2016; Available from: http://docs.boehringer-ingelheim.com/Prescribing\%20 Information/PIs/Spiriva/Spiriva.pdf. Accessed March 20, 2018.

80. Boehringer Ingelheim. Spiriva Respimat [prescribing information]. 2017. Available from: http://docs.boehringer-ingelheim.com/ Prescribing\%20Information/PIs/Spiriva\%20Respimat/spirivarespimat. pdf. Accessed March 20, 2018.

81. Boehringer Ingelheim. Stiolto Respimat [prescribing information]. 2016. Available from: http://docs.boehringer-ingelheim.com/Prescribing $\% 20$ Information/PIs/Stiolto\%20Respimat/stiolto.pdf. Accessed March 20, 2018.

82. European Medicines Agency. Spiolto Respimat [summary of product characteristics]. 2015. Available from: https://www.medicines.org.uk/ emc/medicine/30495. Accessed March 20, 2018.

83. European Medicines Agency. Incruse [summary of product characteristics]. 2017. Available from: http://www.ema.europa.eu/docs/en_GB/ document_library/EPAR_-_Product_Information/human/002809/ WC500167430.pdf. Accessed March 20, 2018.

84. GlaxoSmithKline. Incruse Ellipta [prescribing information]. 2017. Available from: https:/www.gsksource.com/pharma/content/dam/ GlaxoSmithKline/US/en/Prescribing_Information/Incruse_Ellipta/pdf/ INCRUSE-ELLIPTA-PI-PIL.PDF. Accessed March 20, 2018.

85. European Medicines Agency. Anoro [summary of product characteristics]. 2017. Available from: http://www.ema.europa.eu/docs/en_GB/ document_library/EPAR_-_Product_Information/human/002751/ WC500168424.pdf. Accessed March 20, 2018.

86. GlaxoSmithKline. Anoro Ellipta [prescribing information]. 2013. Available from: https:/www.accessdata.fda.gov/drugsatfda_docs/ label/2013/203975s0001bl.pdf. Accessed March 20, 2018.

87. GlaxoSmithKline. Trelegy Ellipta [prescribing information]. 2017. Available from: https:/www.gsksource.com/pharma/content/dam/ GlaxoSmithKline/US/en/Prescribing_Information/Trelegy/pdf/ TRELEGY-PI-MG-IFU.PDF. Accessed March 20, 2018.

88. European Medicines Agency. Eklira Genuair [summary of product characteristics]. 2017. Available from: http://www.ema.europa. eu/docs/en_GB/document_library/EPAR_-_Product_Information/ human/002211/WC500132661.pdf. Accessed March 20, 2018.

89. AstraZeneca Pharmaceuticals LP. Tudorza Pressair [prescribing information]. 2012. Available from: http://www.azpicentral.com/tudorza/ pi_tudorza.pdf. Accessed March 20, 2018.

90. European Medicines Agency. Bretaris Genuair [summary of product characteristics]. 2017. Available from: http://www.ema.europa. eu/docs/en_GB/document_library/EPAR_-_Product_Information/ human/002706/WC500132732.pdf. Accessed March 20, 2018.

91. European Medicines Agency. Duaklir Genuair [summary of product characteristics]. 2017. Available from: https://ec.europa.eu/health/ documents/community-register/2014/20141119130022/anx_130022_ en.pdf. Accessed March 20, 2018.

92. Theravance Biopharma. Revefenacin peak inspiratory flow rate (PIFR) study in COPD. Available from: https://clinicaltrials.gov/ct2/show/ NCT03095456. NLM identifier: NCT03095456. Accessed March 20, 2018.

93. Theravance BioPharma. Theravance Biopharma and Mylan submit new drug application to FDA for revefenacin (TD-4208) in adults with chronic obstructive pulmonary disease. 2017. Available from: http://investor.theravance.com/news-releases/news-release-details/ theravance-biopharma-and-mylan-submit-new-drug-application-fda. Accessed March 20, 2018. 


\section{Publish your work in this journal}

The International Journal of COPD is an international, peer-reviewed journal of therapeutics and pharmacology focusing on concise rapid reporting of clinical studies and reviews in COPD. Special focus is given to the pathophysiological processes underlying the disease, intervention programs, patient focused education, and self management protocols.

This journal is indexed on PubMed Central, MedLine and CAS. The manuscript management system is completely online and includes a very quick and fair peer-review system, which is all easy to use. Visit http://www.dovepress.com/testimonials.php to read real quotes from published authors. 